\title{
Immunosenescence: a key player in cancer development
}

\author{
Jingyao Lian ${ }^{1,2+}$, Ying Yue ${ }^{1,2,3+}$, Weina $Y^{1,2+}$ and Yi Zhang ${ }^{1,2^{*}}$ (i)
}

\begin{abstract}
Immunosenescence is a process of immune dysfunction that occurs with age and includes remodeling of lymphoid organs, leading to changes in the immune function of the elderly, which is closely related to the development of infections, autoimmune diseases, and malignant tumors. T cell-output decline is an important feature of immunosenescence as well as the production of senescence-associated secretory phenotype, increased glycolysis, and reactive oxygen species. Senescent T cells exhibit abnormal phenotypes, including downregulation of CD27, CD28, and upregulation of CD57, killer cell lectin-like receptor subfamily G, Tim-3, Tight, and cytotoxic T-lymphocyte-associated protein 4, which are tightly related to malignant tumors. The role of immunosenescence in tumors is sophisticated: the many factors involved include CAMP, glucose competition, and oncogenic stress in the tumor microenvironment, which can induce the senescence of T cells, macrophages, natural killer cells, and dendritic cells. Accordingly, these senescent immune cells could also affect tumor progression. In addition, the effect of immunosenescence on the response to immune checkpoint blocking antibody therapy so far is ambiguous due to the low participation of elderly cancer patients in clinical trials. Furthermore, many other senescence-related interventions could be possible with genetic and pharmacological methods, including mTOR inhibition, interleukin-7 recombination, and NAD activation. Overall, this review aims to highlight the characteristics of immunosenescence and its impact on malignant tumors and immunotherapy, especially the future directions of tumor treatment through senescence-focused strategies.
\end{abstract}

Keywords: Immunosenescence, Tumor progression, Aging, Tumor microenvironment, Cancer immunotherapy

\section{Background}

The morbidity and mortality rates of various tumors increase with age, and thus, malignant tumors are generally defined as aging diseases $[1,2]$. It should be noted that aging is generally defined as a decline of function in living organisms that occurs in a time-dependent manner and is associated with cancer progression [3]. Despite many studies considering aging as a tumor-suppressor mechanism, most senescent cells behave abnormally, which may eventually lead to serious outcomes, such as

\footnotetext{
*Correspondence: yizhang@zzu.edu.cn

${ }^{\dagger}$ Jingyao Lian, Ying Yue, and Weina Yu contributed equally to this work

1 Biotherapy Center and Cancer Center, The First Affiliated Hospital

of Zhengzhou University, 1 Jianshe East Road, Zhengzhou 450052, Henan, China

Full list of author information is available at the end of the article
}

the development of tumors. Moreover, the accumulation of DNA damage, a critical driver of senescence, and the concomitant events associated with cellular senescence have been shown to participate in tumorigenesis. These studies also documented that cellular senescence is a cellular state closely associated with various physiological processes and aging-related diseases $[4,5]$ and is a double-edged sword in cancer [6]. Nevertheless, small-scale cellular senescence does not represent systematic senescence: only when the scale of cellular senescence gradually increases and affects the whole system, senescent phenotypes and age-related diseases, such as malignant tumors, may occur [7].

The immune system has an ambiguous role in cancer, as it plays an important immune surveillance role in the antitumor response but is also closely associated with original author(s) and the source, provide a link to the Creative Commons licence, and indicate if changes were made. The images or other third party material in this article are included in the article's Creative Commons licence, unless indicated otherwise in a credit line to the material. If material is not included in the article's Creative Commons licence and your intended use is not permitted by statutory regulation or exceeds the permitted use, you will need to obtain permission directly from the copyright holder. To view a copy of this licence, visit http://creativecommons.org/licenses/by/4.0/. The Creative Commons Public Domain Dedication waiver (http://creativeco mmons.org/publicdomain/zero/1.0/) applies to the data made available in this article, unless otherwise stated in a credit line to the data. 
the initiation and progression of tumors [8]. Moreover, immune system aging, also known as immunosenescence, is a natural process that occurs with age and leads to a decline in immune function, thus affecting various aspects of immune functional networks and increasing cancer risk. The concept of immunosenescence was first proposed by Walford in 1964 [9] and is characterized by decreased adaptive immunity, decreased infection resistance, and increased autoimmune risk $[10,11]$. In addition, a variety of factors can dramatically influence this status, such as genetics, exercise, nutrition, previous exposure to microorganisms, sex, and human cytomegalovirus infection [12-16]. It could therefore be possible to target the immune system of the elderly aiming to restore its competence [17]. However, the main obstacle to achieving efficacious immunotherapy is the tumor microenvironment (TME), which may accelerate senescence of the immune system $[18,19]$ : potential targets for rejuvenating the immune system are still a hypothesis. Many studies have shown that the tumor response of innate and adaptive immune systems is different between young and elderly individuals, but its clinical impact and underlying mechanisms are still mostly not understood. For example, $T$ cells are the main effectors of acquired immunity, and their compartment is heavily affected during aging, cumulating defects [20] that can increase immune system damage, disease susceptibility, and the occurrence of malignant tumors in the elderly. Therefore, these lines of evidence indicate that the underlying mechanism of tumorigenesis is closely associated with immunosenescence.

Although our understanding of immunosenescence has steadily progressed over the past few decades and many studies on age-related immune decline have laid the foundation for identifying intervention methods [10, 2123], the interactions between senescence-related changes and different components of the immune system remain unclear. Here, we discuss the most relevant strategies for current research on immunosenescence, focusing on its characteristics and on the various types of immune cells during aging, also highlighting the pivotal role of immunosenescence in tumor progression and immunotherapy. Moreover, we also discuss the interaction between cancer cells and the aging TME, and address how the latter drives tumor progression. Finally, we outline possible future immunosenescence-based interventions that may affect tumor progression.

\section{Concept, process, and hallmarks of immunosenescence}

Senescence is a normal physiological process in which organ function slowly changes with age. When it concerns the immune system, it is termed immunosenescence [9]. As a consequence, immunosenescence is a process of immune dysfunction that occurs with age and includes remodeling of lymphoid organs, leading to changes in the immune function of the elderly. In fact, the process of immunosenescence is regulated by many factors, including aging, chronic inflammation, and changes in the microenvironment (Fig. 1). Moreover, an important distinguishing feature is that the thymus gradually recedes and degenerates with age, resulting in a decrease in $\mathrm{T}$ cell output $[24,25]$. This process is considered to be a manifestation of immunosenescence. Therefore, understanding how to restore thymus function and the production of $\mathrm{T}$ cells provides an effective strategy for immunosenescence intervention. Additionally, inflammation related to advanced age will produce a senescence-associated secretory phenotype (SASP), which also leads to immune system senescence $[15,23$, 25]. Furthermore, intrinsic factors in immune system cells [26-28] as well as potential extrinsic factors that are often overlooked can also cause immunosenescence [29]: its complexity supports the idea that it will lead to the damage of immune response, leading to the occurrence of various diseases.

Consistent with this concept, the identification of hallmarks and characteristics associated with immunosenescence is essential for exploring its impact and significance, especially on tumor progression (Table 1) (Fig. 2). Indeed, some potential targets were already investigated: a recent study has reported that interleukin (IL)-7 and its receptors play a key role in immunosenescence, affecting the balance of the immune system [30] (Fig. 2). More recent studies have shown that, during aging, the cytotoxic activity of immune cells decreases, and the expression of functional molecules associated with cytotoxic activity, such as interferon gamma (IFN- $\gamma$ ), granzyme $B$, and perforin, is also reduced [31-34] (Table 1). Additionally, as the immune system ages, metabolism also changes, showing increased glycolysis and reactive oxygen species (ROS) production, as well as decreased mitochondrial synthesis $[35,36]$. It has been proposed that SASP, a unique characteristic of aging cells, wherein these cells secrete a variety of soluble factors, including growth factors, cytokines, proteases, chemokines, and extracellular matrix (ECM) components, mediates the paracrine activity of senescent cells, thus inducing several senescencerelated diseases, including various malignancies [37].

It has been well documented that the thymus is a lymphoid organ where $\mathrm{T}$ cells differentiate, develop, and mature. Thymus degeneration leads to a decrease in the number and proportion of $\mathrm{CD}^{+}$naïve $\mathrm{T}$ cells, which is one of the main manifestations of immunosenescence $[24,25]$ (Fig. 2). It is therefore likely that $\mathrm{T}$ cells are important immune cells and play a key role in the occurrence and progression of tumors. It is well known 


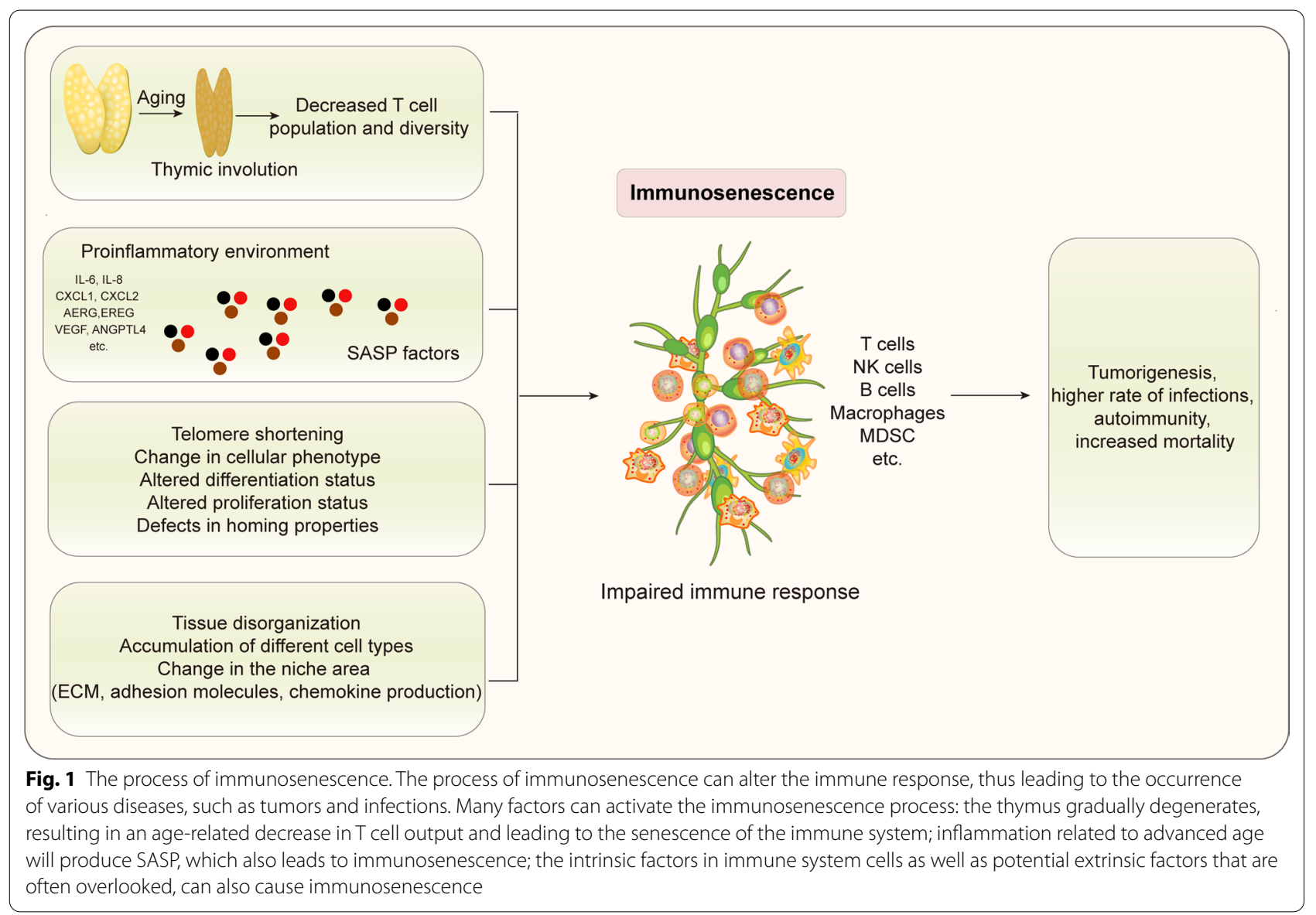

that senescence, anergy, and exhaustion are three important dysfunction states of $\mathrm{T}$ cells in cancer, and they are significantly different in terms of molecular regulation during tumor progression. $\mathrm{T}$ cell senescence is irreversible, as opposed to their anergy and exhaustion, both of which are considered reversible [31, 38-40]. Age-related immune biomarkers, such as the downregulation of the costimulatory molecule CD28 of senescent T cells, have also been employed in several senescence studies [41], which do not express costimulatory molecules such as CD27 and CD28 but express the killer cell lectin-like receptor subfamily G (KLRG-1) and CD57. Therefore, the $\mathrm{T}$ cell phenotype of $\mathrm{CD} 27^{-} \mathrm{CD} 28^{-} \mathrm{CD} 57^{+} \mathrm{KLRG}-1^{+}$ is also an indicator of immunosenescence. Moreover, with the loss of CD27 and CD28, there is an increase in the expression of P16 and P21, which are involved in cell cycle regulation [42] (Fig. 2). P53 can cause cellular senescence [42] by regulating the cell cycle via inhibition of cyclin-dependent kinase (CDK) 4 and CDK6 $[5,43]$ (Fig. 2). Moreover, levels of immune checkpoint-related molecules, such as Tim-3, Tight, and cytotoxic T-lymphocyte-associated protein 4 (CTLA-4), also increase during aging (Table 1). Another hallmark of senescent
T cells is telomere shortening [21, 44] (Fig. 2), which is caused by the continuous replication of $\mathrm{T}$ cells and the decrease in expression of the human telomerase RNA component. It should be noted that, in the process of immunosenescence, the activating receptor expression of natural killer (NK) cell markers NKP30, NKP46, etc., is reduced, while the inhibitory receptor expression of KIR, NKG2C, etc., is increased [45, 46]. With an increase in age, the expression of CD62L and TLR1/4 on monocytes and macrophages is decreased, and the expression of CD11b and TLR5 is increased [28]. However, the expression of CD11a and CD11b in neutrophils did not change significantly [28] (Table 1). Recent studies have identified new types of immunosenescence biomarkers, including circular RNAs (e.g., circular RNA100783) and microRNAs, e.g., MiR-181a, which is reported to be a T cellspecific senescence marker $[47,48]$.

\section{Immunosenescence and cancer}

Generally, the risk of malignant tumors increases with age. In addition to the accumulation of genetic mutations, many researchers believe that immunosenescence may also play an important role in the tumoral process. 
Table 1 The main characteristics of immunosenescence cells

\begin{tabular}{|c|c|c|c|c|}
\hline Category & Markers & Cell types & & References \\
\hline \multirow[t]{7}{*}{ Surface marker } & $\mathrm{CD} 27, \mathrm{CD} 28$ & T cells & $\downarrow$ & {$[41,42]$} \\
\hline & CD57, KLRG-1, Tim-3, TIGIT, CD45RA & T cells & $\uparrow$ & {$[41,42]$} \\
\hline & NKp30, NKp46, DNAM-1, NKG2A & NK cells & $\downarrow$ & {$[28,45,46]$} \\
\hline & KIR, NKG2C, CD57 & NK cells & $\uparrow$ & {$[28,45,46]$} \\
\hline & CD62L, TLR1/4 & Monocytes/macrophages & $\downarrow$ & [28] \\
\hline & CD11b, TLR5 & Monocytes/macrophages & $\uparrow$ & [28] \\
\hline & CD11a, CD11b & Neutrophils & - & {$[28]$} \\
\hline Cell cycle arrest & P16, P21, P53 & T cells & $\downarrow$ & {$[5,42,43]$} \\
\hline $\begin{array}{l}\text { Molecules associated with DNA } \\
\text { damage }\end{array}$ & $\gamma H 2 A X$ & All & $\uparrow$ & {$[64,65]$} \\
\hline TCR signaling machinery & Lck, ZAP70, DLG1, Lat, SLP-76 & T cells & $\downarrow$ & {$[39,64]$} \\
\hline Proinflammatory cytokines & IL-6, IL-8, IFN- ${ }^{\prime}, T N F$ & T cells & $\uparrow$ & {$[31-34]$} \\
\hline Cytokines & IL-7 & T cells & $\downarrow$ & {$[30]$} \\
\hline Inhibitory factors & IL-10, TGF- $\beta$ & T cells & $\uparrow$ & [39] \\
\hline Epigenetic change & SAHF & T cells & $\downarrow$ & {$[37]$} \\
\hline \multirow[t]{3}{*}{ Metabolic alteration } & Glycolysis & T cells & $\uparrow$ & {$[35,36]$} \\
\hline & Mitochondrial biogenesis & T cells & $\downarrow$ & {$[35,36]$} \\
\hline & ROS & T cells & $\uparrow$ & {$[35,36]$} \\
\hline Effector molecules & Perforin, GzmB & T cells & $\downarrow$ & [39] \\
\hline Telomere length & Telomere & All & $\uparrow$ & {$[21,44]$} \\
\hline Telomerase activity & Telomerase & All & $\downarrow$ & {$[21,44]$} \\
\hline SA-b-gal activity & SA- $\beta-$ gal & All & $\uparrow$ & {$[34]$} \\
\hline
\end{tabular}
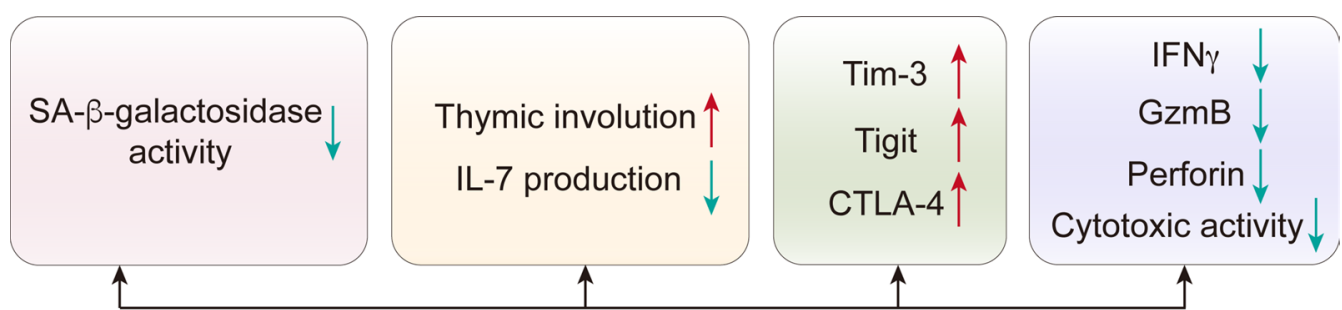

\section{Hallmarkers of Immunosenescence}

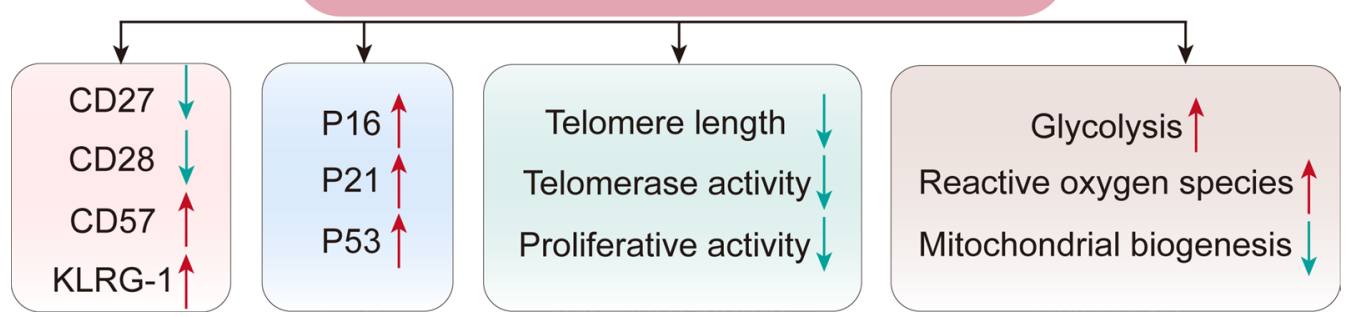

Fig. 2 The main markers of immunosenescence. The main feature of immunosenescence is the degeneration of the thymus, which is accompanied by a decrease in IL-7 secretion. Senescence is accompanied by a decrease in telomere length and telomerase activity. Senescence T cells show reduced SA- $\beta$-galactosidase activity, cytotoxic activity, expression of functional molecules such as IFN- $\gamma$, scarce proliferation, and also arrested cell cycle, due to an increase of the related proteins, P16 and P21. During the remodeling of the immune system with age, changes in immune cell markers are mainly characterized by the loss of CD27 and CD28 expression and the increase in CD57 and KLRG-1 expression. During aging, glycolysis and ROS production are increased, while mitochondrial synthesis is decreased 
DeSantis et al. [49] found a higher risk of tumorigenesis in the elderly group. By analyzing the age distributions of 100 different tumors, Palmer et al. [24] concluded that the immune system may play an important role in tumor development. Vatter et al. [50] performed a phenotypic analysis of mammary epithelial cells from 57 women (16-91 years old) and showed that accumulation of lumen and progenitor cells with age may lead to an increased risk of carcinogenesis.

Many factors in the TME can induce the senescence of immune cells and dramatically affect their function. Multiple studies have shown that an immune system disorder in the elderly may promote tumor growth and induce $\mathrm{T}$ cell senescence, such as an increase in the proportion of tumor-associated macrophages and regulatory $\mathrm{T}$ cells (Tregs) [51-55]. The molecules and pathways associated with $\mathrm{T}$ cell senescence in the TME are shown in Fig. 3 [39]. Several studies have reported that tumor-derived endogenous cyclic adenosine monophosphate (cAMP) induces $\mathrm{T}$ cell senescence by inhibiting tumor-specific effector $\mathrm{T}$ cells in hypoxic microenvironment $[56,57]$. In addition, tumor cells activate the PKA-CREB and P38 pathways by producing cAMP, thereby causing DNA damage and senescence of $\mathrm{T}$ cells $[51,53,58-63]$. Similarly, glucose competition triggers ATM-related DNA damage, activates the ERK1/2 and P38 pathways, and cooperates with STAT1/3, leading to T cell cycle arrest and aging. The activation of ATM and AMPK pathways induced by glucose can also cause DNA damage and T cell senescence, in which AMPK activates P38 by binding to TAB1 protein and downregulating the telomerase reverse transcriptase gene $[64,65]$. P38 inhibits cell cycle progression by activating P53, P21, and P16 [64]. Moreover, aging $\mathrm{T}$ cells preferentially employ anaerobic glycolysis to generate energy, which results in mitochondrial dysfunction and increased reactive oxygen species (ROS) generation [36]. The NFkB, C/EBP $\beta$, and cGAS-STING pathways also play a key role in the induction of $\mathrm{T}$ cell senescence [66]. Furthermore, the activation of Toll-like receptor 8 signaling in tumor cells can enhance antitumor immunity by blocking the induction of senescent $\mathrm{T}$ cells and tumor-specific $\mathrm{T}$ cells in vitro and in vivo and reversing their inhibitory effect [63].

In addition to basic research, several preclinical and clinical studies have been conducted on immunosenescence. Studies have shown that immunosenescence, especially that of $\mathrm{CD}^{+} \mathrm{T}$ cells, plays a pivotal role in the pathogenesis and treatment of patients with breast cancer [67]. Decreased expression of IFN signaling in $\mathrm{CD}^{+} \mathrm{T}$ cells in aged mice was identified in a mouse model of breast cancer [68]. The senescent microenvironment is closely associated with tumor metastasis and invasion, and the metabolism of $\mathrm{T}$ cells in the TME also changes with age. Compared with young patients with melanoma, ECM rearrangement resulting from Hyaluronan And Proteoglycan Link Protein 1 changes in elderly patients can cause melanoma cells to be more invasive and prone to distant metastasis [69]. The increased age-related sFRP2 secreted by fibroblasts also promoted angiogenesis and metastasis of melanoma cells [70]. In contrast to the above findings, senescence was also found to improve cancer prognosis. In various mouse models, tumor proliferation was found to be slower in elderly mice, such as MC38, B16, and 4T1 tumor models [71]. In 1973, a retrospective study of 226 patients with colorectal cancer aged 80 years and older found that the prognosis of elderly patients was better than that of young patients [72]. Older patients with bronchial cancer have slower tumor growth and reduced metastasis, which is believed to be due to the host aging factors that hinder the growth and spread of aggressive tumors [73]. In the elderly group of Engelbreth-Holm-Swarm cancer and B16F10 melanoma mouse models, tumor growth and metastasis sizes were lower and the subjects had a higher survival rate [74, $75]$. Another study retrospectively analyzed the histological report of 1869 women with breast cancer and found that the incidence of invasive ductal carcinoma increased in patients $<39$ years of age [76]. Recent research has highlighted that the upregulated methylmalonic acid in the serum of the elderly induces the expression of SOX4 and thus triggers the ability of transcriptional reprogramming, which can make cancer cells more aggressive [77]. Overall, these different research results indicate that age is closely associated with tumorigenesis.

Chemotherapy can also induce $\mathrm{CD} 8^{+} \mathrm{T}$ cell senescence in patients with breast cancer [67]. In a preclinical mouse model of pancreatic ductal adenocarcinoma, T/P drugs induced senescence of pancreatic cancer cells and activated SASP-dependent vascular remodeling, which not only enhances the uptake and efficacy of chemotherapy drugs but also promotes the infiltration of $\mathrm{T}$ cells into tumor tissues [78]. Altogether, these findings indicate that immunosenescence is linked to the occurrence and progression of tumors.

\section{Changes in senescence-related immune cell subsets in the TME}

Immunosenescence not only affects the innate immune system, which includes NK cells and macrophages, but also reduces the function of the acquired immune system, including $\mathrm{T}$ cells and B cells (Fig. 4). Thus, immune system senescence reflects the senescence of various immune cell subpopulations. 


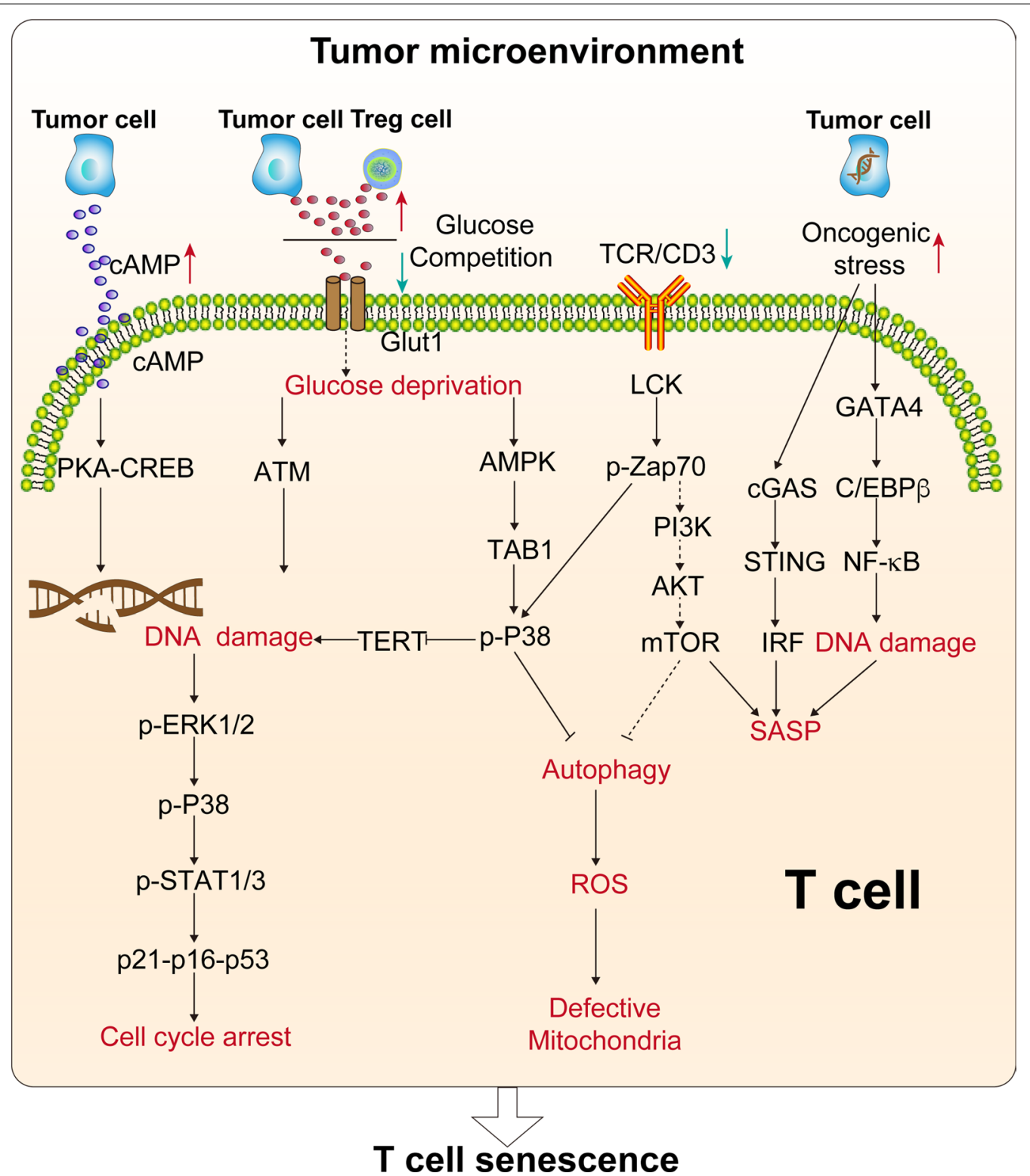

Fig. 3 T cell senescence-related signaling pathways. Tumor-derived CAMP can be transferred to T cells, activating the PKA-CREB signaling pathway, which in turn activates DNA damage and induces T cell senescence. T cell competition for glucose triggers ATM-related DNA damage, activates the ERK1/2 and P38 pathways, and interacts with STAT1/3, which leads to T cell cycle arrest and aging. Activation of the P38 pathway induces the downregulation of TERT, leading to DNA damage. The downregulation of TCR signaling can activate the P38 pathway and inhibit the PI3K-AKT-mTOR signaling pathway, thereby inactivating autophagy and inducing mitochondrial dysfunction and ROS production in senescent T cells. DNA damage induced by the GATA4-C/EBP $\beta$ signaling pathway leads to increased secretion of SASP molecules. Similarly, the cGAS-STING signaling pathway also leads to increased secretion of SASP molecules

\section{NK cells}

NK cells are a key component of innate immunity and, to a large extent, promote the antitumor immune response $[79,80]$. The function of NK cells, such as immune surveillance, is also affected by age-related changes. The number of mature NK cells in all lymphoid organs and the expression of T-box protein, expressed in T cells (also called TBX21), and eomesodermin were both significantly reduced in aged mice [81]. Two subpopulations of NK cells, immature $\mathrm{CD} 14^{+} \mathrm{CD} 56^{\mathrm{dim}}$ and mature $\mathrm{CD} 14^{+} \mathrm{CD} 56^{\text {bright }}$, are associated with aging and remodeling of mature NK cell subsets, and the reduced expression of activated receptors may promote the escape of NK cells in the elderly [45]. Moreover, 


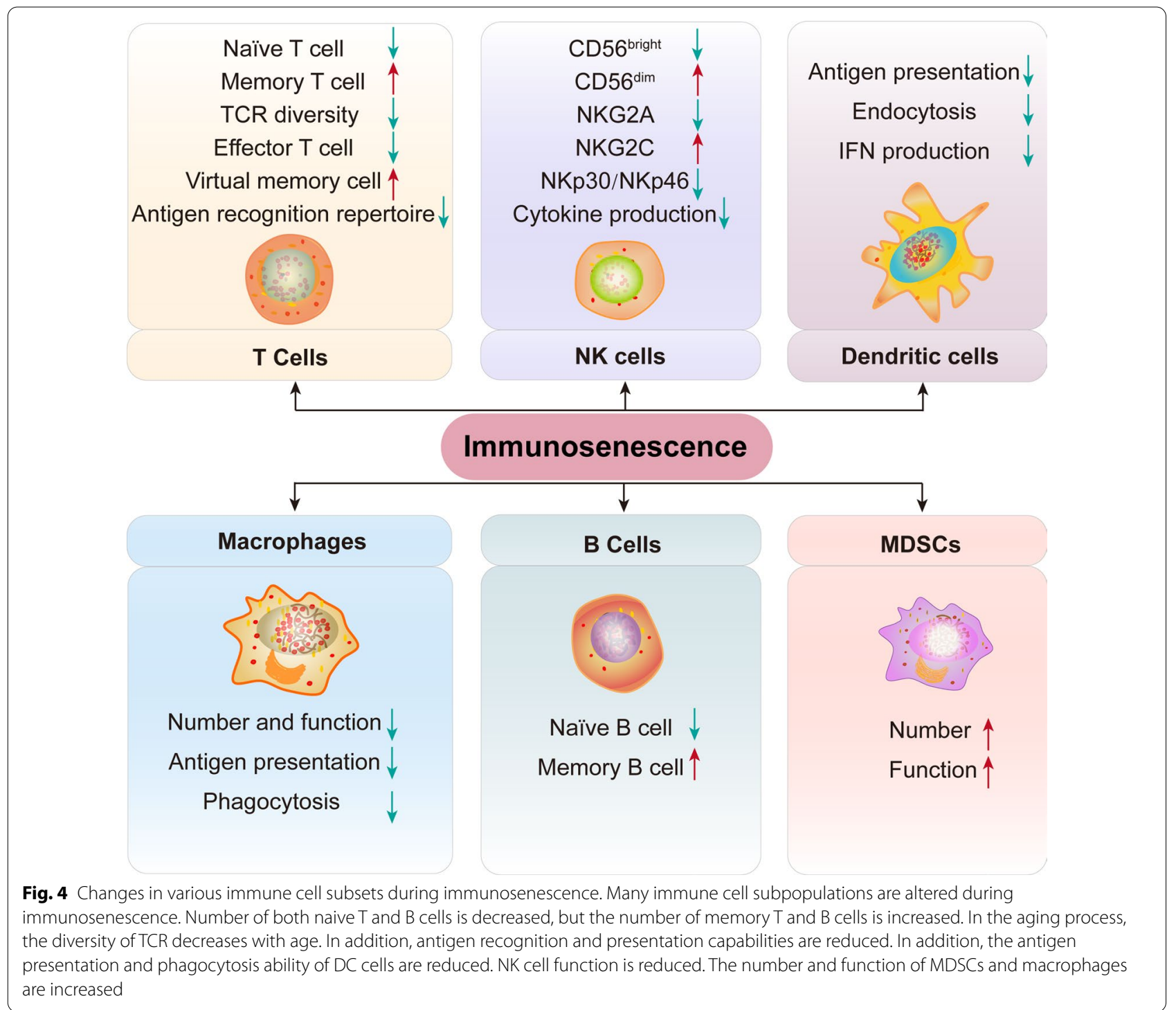

NKp30, NKp46, and DNAM-1 are NK activation receptors involved in the recognition and lysis of different tumors, such as hematological malignancies [82], melanoma [83], and ovarian cancer [84]. Therefore, changes in the expression of these activated receptors in the elderly may affect the immune monitoring function of NK cells $[85,86]$. The NK cell compartments in elderly patients with acute myeloid leukemia (AML) are also remodeled, as evidenced by the reduced output of immature CD56 ${ }^{\text {bright }}$ cells and the accumulation of highly differentiated CD56 ${ }^{\text {dim }}$ NK cells, which is associated with disease progression and survival [81, 87, 88]. Moreover, a clinical trial (NCT00799799) in which NK cells mismatched by KIR ligands were infused after immunosuppressive chemotherapy in elderly patients with AML showed that NK cell transfer is safe and feasible in elderly patients [89].

\section{T cells}

\section{Naïve T cells}

Naïve $\mathrm{T}$ cells are a very relevant factor in immunosenescence research [90]: their generation is completely dependent on the thymus function, so the degeneration of the thymus is of great significance to the study of human immunosenescence [91, 92]. Degeneration of the thymus leads to structural changes and declines in function, which ultimately leads to a significant reduction in the thymus output of naïve $\mathrm{T}$ cells [93-95], thereby reducing the $\mathrm{T}$ cell antigen receptor diversity pool and ultimately leading to the destruction of $\mathrm{T}$ cell 
homeostasis. Therefore, degeneration of the thymus is the cause of age-related failure of the adaptive immune system $[95,96]$.

\section{Memory T cells}

Some studies also documented that memory T cells gradually accumulate with age [66, 97-99]. Memory $\mathrm{T}$ cells with a naïve phenotype also accumulate with age [100], and the number and ratio of memory $\mathrm{CD}^{+} \mathrm{T}$ cells in the elderly are usually higher, affecting their immune function. Collectively, these studies have demonstrated that central memory $\mathrm{CD}^{+} \mathrm{T}$ cells represent the majority of memory $\mathrm{CD}^{+} \mathrm{T}$ cells in aged mice $[101,102]$. These virtual memory $\mathrm{CD}^{+} \mathrm{T}$ cells accumulate and exhibit characteristics consistent with aging.

\section{Stem cell memory T cells (TSCM)}

TSCM represent a small group of memory $\mathrm{T}$ cells with enhanced proliferation and differentiation characteristics, and they can produce more terminally differentiated daughter cells expressing effector molecules, which is of great significance for cancer immunotherapy [103, 104]. A study showed that there was no difference in the frequency of TSCM between the young and old groups [105]. Graham et al. also found that age significantly affected the distribution of other $\mathrm{T}$ cell subsets, but does not affect the frequency of TSCM [106]. Similarly, a study has shown that TSCM in young and elderly subjects is maintained through continuous proliferation and shows limited telomere length erosion and high expression of telomerase and Ki67 [107]. Overall, these results indicate that TSCM exists throughout the life process. However, a study has shown that the frequency of $\mathrm{CD} 4^{+}$ and $\mathrm{CD}^{+}$TSCM is relatively stable at different ages, and the absolute number of CD8 ${ }^{+}$TSCM decreases with age [108]. Anis et al. found that aging is related to the loss of Wnt/ $\beta$-catenin signaling in CD4 ${ }^{+}$TSCM and the increase of Dickkopf-related protein 1 (an inhibitor of the Wnt/ $\beta$-catenin pathway). This study suggested that targeting Wnt/ $\beta$ could reverse the defect of TSCM through the catenin pathway, which may be a feasible method to restore and maintain immune homeostasis [109]. These results indicate that it is possible to further optimize culture conditions to obtain T cells with stem cell-like properties more efficiently, thus being able to further maintain and improve cancer immunotherapy.

\section{CAR-T cells}

Chimeric antigen receptor $\mathrm{T}$ (CAR-T) cell therapy is being developed as a potential treatment for patients with advanced hematological malignancies [110-116]. It has been reported that CAR-T cell therapy shows high response rates to B-ALL patients in different age groups [117-119]. However, a global study on CAR-T cells showed that this therapy is very effective on young patients with recurrent B-ALL [120], but did not discuss the impact on elderly patients, maybe due to the negative effect of the aging microenvironment. Moreover, CAR-T cell therapy is highly dependent on functionally active $\mathrm{T}$ cells, so $\mathrm{T}$ cell senescence plays a key role in immunosuppression and evasion of hematological tumors and solid tumors [121], underlying some practical challenges in this approach: the reconstructed and expanded CAR-T cells are exposed to the patient's tumor microenvironment, thereby inducing the senescent phenotype of CAR-T [122, 123]. Gabriele et al. reported that CD57, a $\mathrm{T}$ cell senescence marker, can quickly and efficiently transfer from glioblastoma stem cells to CAR-T cells, leading to its senescence [124]. Moreover, they also found that patient-derived glioblastoma stem cells were killed by CD133-specific CAR-T cells, but at the same time induced the expression of CD57, thereby inducing CAR-T senescence [125]. Furthermore, when CAR is introduced into $\mathrm{T}$ cells with unique $T$ cell receptor (TCR) specificity, the presence of TCR antigen causes the loss of $\mathrm{CD}^{+} \mathrm{CAR}-\mathrm{T}$ cell potency, which is related to $\mathrm{T}$ cell senescence, exhaustion, and apoptosis [126]. Moreover, recent studies have shown that uPAR-specific CAR-T cells can effectively eliminate senescent cells in vitro and in vivo and prolong the survival of lung adenocarcinoma mice [127]. These findings do suggest therapeutic potential of CAR-T cells for senescence-related diseases. In general, restoring the function of senescent CAR-T cells is the key to enhancing the antitumor effect of modified T cells.

\section{$\mathrm{CD4}^{+} \mathrm{T}$ cells}

The low survival rate of patients with glioblastoma is associated with immunosenescence of postoperative $\mathrm{CD}^{+} \mathrm{T}$ cells [128]. The accumulation of the programmed cell death protein $1(\mathrm{PD}-1)^{+}$memory phenotype $\mathrm{CD}^{+} \mathrm{T}$ cell subsets gradually increases with age and is the predominant subset in the aging phase of normal mice; this process is strongly accelerated during leukemia [129]. It has been reported that CD39 expression during aging reduces the number of $\mathrm{CD} 4^{+} \mathrm{T}$ cells [130]. Moreover, Tregs gradually accumulate with age [131-133] and the percentage of $\mathrm{CD} 4^{+} \mathrm{CD} 25^{+}$Tregs in the peripheral blood of elderly mice significantly increased [134]. Similarly, in Lewis lung cancer mouse models and patients with lung cancer, Tregs infiltration and Foxp3 mRNA expression levels were higher in the elderly group than in the younger group $[135,136]$. 


\section{B cells}

After differentiation into plasma cells, B cells are the sole producer of antibodies and play a unique role in immunity [137]. The age-related remodeling of the B cell compartment may be the result of unbalanced fate selection in the hematopoietic progenitor cell population, autonomous changes in B cells, and external signals [138, 139]. The aging process leads to changes in the distribution of mature B cell subsets and impaired activation after stimulation $[23,140]$. With increasing age, the proportion and number of $\mathrm{CD} 19^{+} \mathrm{B}$ cells in peripheral blood decrease and the function of $B$ cells is impaired, which is reflected in the decreased expression of the autoimmune regulator AIRE and autoantigen genes in thymic B cells [141, 142]. In mice, the turnover of mature spleen B cells also decreases with age $[143,144]$.

\section{Other cells}

Dendritic cells are the central coordinators of immune response and play a key role in immunity and maintenance of tolerance. Moreover, their functions such as antigen presentation, endocytosis, and IFN production, are also reduced in aged individuals $[145,146]$. The ability of neutrophils to phagocytose pathogens decreases with age [147]. The phagocytosis and antigen presentation ability of macrophages change with age is not clear [147]. Age-modified tissue-specific macrophages and neutrophils may cause chronic low-grade inflammation, which is related to macrophage-mediated immunosuppressive disorders, together leading to the development of many diseases, including cancer [147]. Furthermore, increased levels of myeloid-derived suppressor cells (MDSCs) are observed in the bone marrow, blood, and spleen of tumor-bearing aged mice; this accumulation plays a detrimental role because MDSC-induced immunosuppression impairs senescence and tumor cell clearance and interferes with energy metabolism and maintenance of tissue protein homeostasis [58]. SASP-expressing senescent cells secrete several kinds of chemokines and cytokines, which recruit MDSCs to local regions and result in immune escape and tumor cell metastasis [58]. He et al. [148] found that in the first few weeks of mice and humans' development, MDSCs can suppress $\mathrm{T}$ cells, and thus the accumulation of MDSCs is considered to result from a pathological process or pregnancy. The expansion of MDSCs may not only promote immunosenescence but may also induce harmful age-related bystander effects in host tissues by secreting TGF- $\beta$ and IL-10 [149]. As shown in Fig. 5, the loose arrangement of the ECM in the aging microenvironment may be one of the causes of metastasis in elderly patients with tumors $[69,70]$. Furthermore, in aging TME, changes in immune cell function and secretion of SASP molecules dramatically affect tumor progression [18]. Therefore, it is important to note the changes in senescence-related immune cell subsets in cancer research.

\section{Immunosenescence and tumor immunotherapy}

Aging is a paramount risk factor for most cancers. Although the number of elderly people with cancer has increased dramatically, their inclusion in clinical studies is usually insufficient, as patients over 75 years of age represent less than $10 \%$ of patients with cancer [150,151]. This hampers the provision of optimal medical services to the growing population of elderly patients with cancer. Nevertheless, novel cancer treatments targeting elderly patients are being prioritized due to the increasing aging population. Immunotherapy in malignant tumor treatment has dramatically changed the prospects of cancer treatment and improved the survival of patients with cancer. However, the results of immunotherapy in elderly and young patients are inconsistent, which is likely due to different types, different stages of tumor development, and concomitant diseases. Moreover, the association between immune-related adverse events and age is controversial, and thus analyzing the latest data on the efficacy of immunotherapy in elderly patients with cancer is paramount.

Immunosenescence may affect the response to blocking antibody therapy in patients with non-small cell lung cancer [152]. Importantly, a preclinical study highlights that the efficacy is poorer in older mouse models than in younger mouse models, indicating that age may have a significant effect on different tumor types and various physiological states [153]. Immune checkpoint blocking (ICB) antibody therapy has been used to treat a variety of tumors. Although age is one of the greatest risk factors for tumorigenesis, studies and clinical trials on the effects of host age on the outcome of ICB are limited and the influence of the microenvironment of the elderly on the response to immunotherapy is largely ignored. Little is known about ICB general tolerance and effect in the elderly. One study reported that age limits ICB antibody therapy efficacy in aged triple-negative breast cancer-bearing mice [68]. Kugel et al. [154] analyzed the relationship between age and anti-PD-1 response in 538 patients with melanoma and found that those over 60 years of age exhibited a better response to anti-PD- 1 than those aged $<60$ years. Elderly patients have also been observed to safely tolerate anti-PD-1/ programmed cell death 1 ligand 1 (PD-L1) antibody treatment, with efficacy and toxicity effects similar to those observed in younger patients. A meta-analysis of randomized trials showed that although anti-PD-1 drugs are effective for both young and elderly patients, the risk of death among elderly patients is comparable 


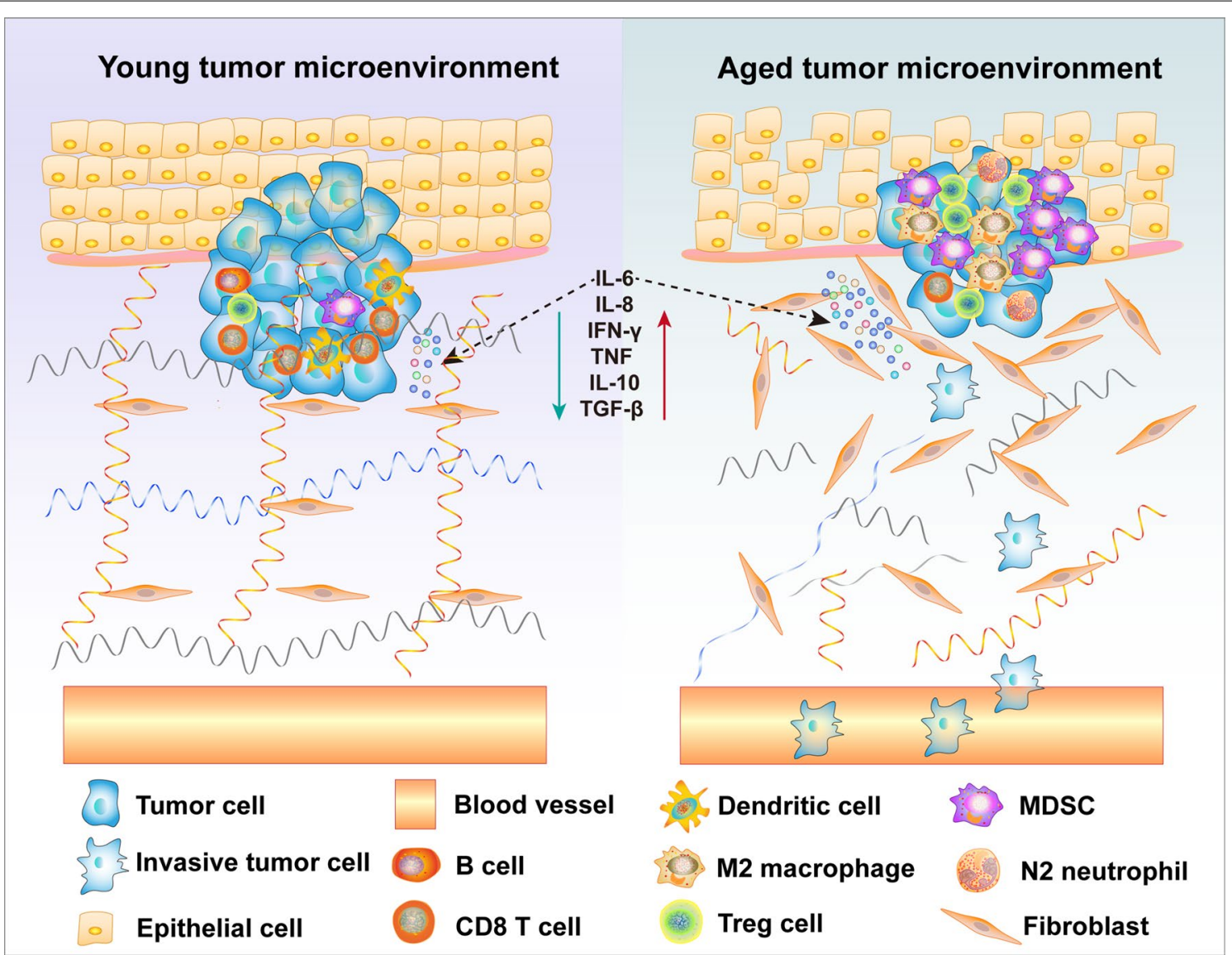

Fig. 5 The effect of an aging TME on tumor progression. Age-induced changes in the structure and function of the ECM promote the occurrence and development of tumors. The integrity of the ECM is greatly reduced with age, which can promote the development of cancer. In the aging TME, stromal cells are disordered and loosely arranged, which may also lead to tumor progression and metastasis. Moreover, age-induced secretion of SASP, such as the accumulation of several factors, including IL-6, IL-8, and IL-10, is a key factor in inducing tumorigenesis and progression. The aging TME also exhibits an infiltration of immunosuppressive cells, such as MDSCs and Tregs. The increase in immunosuppressive M2 macrophages and N2 neutrophils may further promote immunosuppression, while immunosenescence of effector T cells, NK cells, macrophages, and DCs significantly reduces their cytotoxic activity, leading to tumor escape and tumor progression

or improved compared to that of patients subjected to control interventions, with no increased toxicity [155158]. Although the toxicity in elderly patients was not increased, patients who experienced lethal toxic effects appeared to be older than those not suffering from lethal toxic effects [159]. Padron et al. [153] found that in a melanoma mouse model, anti-CTLA-4, anti-PD-1, and anti-PD-L1 antibodies were very effective in treating young mice. However, in the aged group, anti-PDL1 treatment had no effect, whereas anti-CTLA-4 and anti-PD-1 treatment showed a positive effect. Another retrospective study indicated that anti-PD1 antibodies appear more effective and well tolerated in elderly ( $\geq 75$ years old) patients with advanced melanoma than in younger patients [160], but these experiments did not conduct strict age-treatment subgroup analysis. Moreover, in an oral cancer tumor-bearing mouse model, the tumor regression of aged mice after antiPD-L1 treatment was faster than that of young mice [161]. Furthermore, IFN signaling and antigen presentation were reduced in the TME of aged mice and patients with triple-negative breast cancer [68].

It is clear that more studies considering the high incidence of tumors in the elderly are needed, and that it is important to investigate the effect of ICB antibody therapy and its associated mechanisms in the elderly. In most studies, the number of elderly patients in the ICB antibody therapy group is small and data on the safety and toxicity of ICB antibody treatment are limited; therefore, the effect of ICB antibody therapy on elderly patients has not been fully elucidated [162]. Exploring the underlying mechanisms accelerating tumor growth and affecting immunotherapy in elderly patients is a challenging and urgent need. Therefore, further studies and clinical 
experiments are required to carefully evaluate the impact of ICB antibody therapy on the elderly.

\section{Clinical implications, evaluations, and intervention}

The clearest evidence of age being the biggest risk factor for age-related diseases, and the accumulation of senescent cells is closely related to the occurrence of many chronic diseases $[163,164]$. It has been reported that the reduction of senescent cells through genetic and pharmacological methods can prevent and alleviate various senescence-related diseases $[165,166]$. Therefore, it will be critical to further understand how to test these interventions in humans and accelerate their widespread use (Table 2).

In 1939, a study found that limiting the caloric intake of mice and rats could prolong lifespan, which proved for the first time that the aging process is plastic [167]. Some follow-up studies also found the same phenomenon in primates $[168,169]$. It is worth noting that dietary restrictions not only increase lifespan but also inhibit the development of age-related diseases [170]. These findings further support the notion that life extension is related to aging and increased healthy lifespan.

One of the main characteristics of aging is the involution of the thymus, which leads to a decrease in the production of $\mathrm{T}$ cells, leading to immunosenescence. It has been found that there are many different ways to restore the structure and function of the aging thymus. Typically, a study has found that replenishing young transplantable thymic epithelial cells to middle-aged or defective thymuses can lead to increased thymus growth and $\mathrm{T}$ cell production, which directly drives the growth of degenerated thymus [171]. Similarly, a report has shown that the injection of a plasmid vector carrying FOXN1-cDNA into the thymus of elderly mice would cause a partial rescue in the size of the thymus and the number of thymocytes [172]. Therefore, targeted FOXN1 gene therapy may also be a great hope for revitalizing the structure and function of the aging thymus. IL-7 targeting the thymus of the elderly may also restore the development of $\mathrm{T}$ cells in the elderly. In line with this, it was reported that the IL-7 fusion protein, that is, IL-7 binding to the $\mathrm{N}$-terminal extracellular domain of CCR9, could restore the thymus structure in elderly individuals [173], showing that targeted cytokine therapy has broad prospects (Table 2). Studies have also shown the relationship between physical exercise and improvement of thymic function in elderly patients: individuals who maintained physical exercise showed a slowdown in thymic output decline and changes in inflammatory markers, such as a decrease of IL- 6 and an increase of IL-7 and IL-15 in serum, which may promote thymus function [174]. The use of thymus-targeted cytokines may be beneficial, but caution is needed because of adverse effects. Moreover, the development of effective interventions for age-related thymic degeneration requires further investigation.

Short telomeres can also trigger age-related diseases and shorten the lifespan of mice and humans. By activating telomerase to avoid telomere shortening, mice were seen to have longer telomeres, less DNA damage and aging, and extended lifespan [175].

Recently, it has been proven that drug intervention can slow down the aging phenotype to alleviate age-related functional decline [176]. Metformin, a widely prescribed antidiabetic drug, has been shown to alleviate aging in preclinical studies [177]. Positive effects on aging were also observed in mice, but these studies were carried out in short-lived mouse models that were prone to develop

Table 2 List of the current clinical trials or drugs that are targeting immunosenescence

\begin{tabular}{|c|c|c|c|}
\hline Treatment & Clinical trial/drugs & Target & References \\
\hline Third-gen CAR-T cells containing CD28 + CD137 & NCT02186860 & CD28 & {$[41]$} \\
\hline $\begin{array}{l}\text { Second-gen CMV-selected CAR-T cells against HER2 } \\
\text { containing CD28.zeta signaling domain }\end{array}$ & NCT01109095 & CD28 & {$[41]$} \\
\hline TAB08 & NCT01990157 & CD28 & {$[41]$} \\
\hline $\mathrm{IL}-7$ & $\mathrm{IL}-7$ & Thymic & {$[19]$} \\
\hline KGF (keratinocyte growth factor) & KGF & Thymic & [19] \\
\hline IL-22 & $\mathrm{IL}-22$ & Thymic & [19] \\
\hline Ghrelin & Ghrelin & Thymic & {$[19]$} \\
\hline CDK4 inhibitors & CDK4 inhibitors & CDK4 & {$[166]$} \\
\hline Rapamycin & Rapamycin & MTOR & {$[166]$} \\
\hline Metformin & Metformin & Mitochondrial respiration & {$[166]$} \\
\hline NAD precursors & NAM $\backslash N R$ & NAD metabolism & {$[166]$} \\
\hline Sirtuin-activating compounds & \begin{tabular}{l} 
Resveratrol or trans-resveratrol\SRT2104\} $\\
{\text { nicotinamide riboside }}$ & Sirtuin & [212] \\
\hline
\end{tabular}
\end{tabular}


cancer in some cases [178]. In subsequent recent studies, in the relatively long-lived $\mathrm{C} 57 \mathrm{BL} / 6$ mice and genetic hybrid mice, a similar phenomenon was observed [179, 180]. Furthermore, a retrospective analysis showed that the life span of diabetic patients treated with metformin increased compared with individuals without diabetes [181] (Table 2).

MTOR is a multifunctional protein that participates in many signaling pathways including growth factors, energy status, nutrient utilization, and various stressors [182]. Much of the literature suggests that the genetic regulation of mTOR signal transduction can slow the aging of many organisms [183-185]. These signal modulations, including mRNA translation, transcription, autophagy, and mitochondrial function, have been shown to mediate extended lifespan [186]. Moreover, the rapamycin-FKBP12 binding event caused mTORC1 to destabilize, thereby inhibiting mTORC1. As an effective anticancer drug, rapamycin can slow or reverse many age-related changes [187-189] (Table 2). Studies have provided evidence that rapamycin only prolongs lifespan through antitumor mechanisms, thereby inhibiting the main pathological changes in mice [190, 191]. Rapamycin can reverse the increased SASP of senescent cells [192194] (Table 2). At present, research on the mTORC1 pathway has the strongest clinical evidence, proving that it can be used as a feasible strategy to prevent aging.

$\mathrm{NAD}^{+}$is a coenzyme that catalyzes a wide range of cellular metabolic functions through cellular redox reactions and is converted into NADH through it. Much of the literature suggests that $\mathrm{NAD}^{+}$declines in many tissues during the aging process, including adipose tissue, skeletal muscle, brain, liver, pancreas, heart, spleen, kidney, and lungs, leading to various age-related pathophysiology developments [195-197]. However, NAD ${ }^{+}$ is not absorbed by cells, making direct supplementation impossible. Nonetheless, $\mathrm{NAD}^{+}$supplements have a protective effect during aging, and nicotinamide is the main precursor in $\mathrm{NAD}^{+}$biosynthesis. NAMPT catalyzes the conversion of nicotinamide and $5^{\prime}$-phosphoribose pyrophosphate to nicotinamide mononucleotide (NMN) [198]. NMN can also be synthesized by the NR kinase NRK1 through another $\mathrm{NAD}^{+}$intermediate, nicotinamide ribose (NR). Thus, NMN and ATP are converted into $\mathrm{NAD}^{+}$by NMN adenylate transferase NMNAT13. According to reports, NR and NMN have a protective effect in a number of age-related disease models, by increasing the pool of precursors and thus $\mathrm{NAD}^{+}$levels in the body, both of which have been tested in murine and invertebrate aging studies [195, 197, 199]. NR also increases the lifespan of yeast replication [200], and both NR and NMN increase the lifespan of worms [201]. In mice, NR causes a wide range of beneficial effects, including a moderate lifespan extension [202]. These studies also documented that NMN has a significant effect on improving disease conditions and reducing agerelated physiological decline [203-206]. NMN treatment can also restore glucose-stimulated insulin secretion in elderly mice [207]. Previous studies have demonstrated that NMN can effectively alleviate age-related physiological decline in wild-type mice fed with conventional feed [205]: through a transporter called slc12a8, 26-monthold mice (equivalent to 70 human years) that took NMN increased their $\mathrm{NAD}^{+}$levels to close to 3 months old (equivalent to 12 human months). The content level in young mice increased the cell energy in aged mice [208]. In general, these findings strongly indicate that NMN and $\mathrm{NR}$ are key endogenous compounds in $\mathrm{NAD}^{+}$biosynthesis and can be used as effective treatments to prevent many age-related diseases.

Our understanding of the molecular mechanisms that lead to aging has rapidly increased, creating new opportunities for intervention in the aging process. These studies have yielded two notable findings. First, the number of genes that can extend lifespan is much higher than expected, which indicates that the level of plasticity during aging is highly. Second, genes that control aging are highly conserved in humans. These pathways are conserved over a wide range of evolutionary distances, and targeting these pathways in model organisms prolongs lifespan. Together, these evidences indicate that the mechanisms that interfere with aging may have great implications.

\section{Conclusion and perspectives}

Overall, immune parameters are different between the young and the elderly. Indeed, the aging process particularly affects the immune response: this imbalance of the immune system may be involved in the development of tumors. Currently, there are relatively few systematic studies on immunosenescence. Therefore, understanding the level of age-related immune changes requires a systematic approach to studying the multiple interacting factors of immune response. As indicated above, immunosenescence is a complicated and inevitable process that seems to affect tumor progression and the efficiency of antitumor immune responses in the elderly individuals.

The impact of immunosenescence on tumor progression indicates that it is necessary to better understand its role in treating and driving tumor progression. First, the reduction of $\mathrm{T}$ cell output caused by thymic degeneration can be achieved through the intervention with immune regulatory factors, i.e., by supplementing IL-7 [30], thereby restoring $\mathrm{T}$ cell production and thymic function. Furthermore, the rejuvenation strategy for the thymic matrix microenvironment has been proven to 
successfully restore the thymus function of the elderly. Second, by intervening the SASP during the aging, combined therapy can be used to achieve better therapeutic effects. For example, the SASP induced by chemotherapy increases the sensitivity of PD-1 and chemotherapy, thereby reducing tumor progression and metastasis [78]. Finally, emerging evidence suggests that the aging microenvironment largely contributes to age-related decline in immune function and may also provide potential targets for rejuvenating the immune system [18].

Moreover, although basic and clinical research on aging has made great progress, the existing immunological techniques cannot thoroughly analyze the complexity of the immune system. For example, the 6-8-week mouse model is the most frequent model employed in tumor studies; thus, the model may not be entirely applicable to humans [209, 210]. Furthermore, the definition of the corresponding age between humans and mice is still under discussion [210, 211], and a more convincing in vivo aging model between the age of immunity and time series should be established [211]. Therefore, a more profound understanding of immunosenescence, especially of its underlying mechanisms and therapeutic targets in malignant tumors, is urgently needed to reduce this growing public health burden. In the future, targeting immune senescent cells may be a novel interventional opportunity in cancer patients.

\begin{abstract}
Abbreviations
CAMP: Cyclic adenosine monophosphate; CAR-T: Chimeric antigen receptor; CTLA-4: Cytotoxic T-lymphocyte-associated protein-4; ECM: ExtracelIular matrix; ICB: Immune checkpoint blocking; IFN-y: Interferon gamma; IL-7: Interleukin-7; KLRG-1: Killer cell lectin-like receptor subfamily G; MDSC: Myeloid-derived suppressor cells; NK: Natural killer; NMN: Nicotinamide mononucleotide; NR: Nicotinamide ribose; PD-1: Programmed cell death protein; PD-L1: Programmed cell death 1 ligand 1; ROS: Reactive oxygen species; SASP: Senescence-associated secretory phenotype; TME: Tumor microenvironment; Tregs: Regulatory T cells; TSCM: Stem cell memory T cells.
\end{abstract}

\section{Acknowledgements}

We would like to thank Editage (www.editage.cn) for English language editing.

\section{Authors' contributions}

$Y Z$ conceptualized this review, decided on the content, and JL, YY, and WY wrote the manuscript. $J, Y Y$, and $W Y$ prepared the figures. $Y Z$ revised the manuscript. All authors read and approved the final manuscript and agreed to be accountable for all aspects of the work. All authors read and approved the final manuscript.

\section{Funding}

This work was supported by grants from the National Natural Science Foundation of China (Grant Nos. 9194230059, 81771781, and 81602024) and the State's Key Project of Research and Development Plan (Grant No. 2016YFC1303500)

\section{Availability of data and materials}

Not applicable.

Ethics approval and consent to participate

Not applicable.
Consent for publication

Not applicable.

\section{Competing interests}

The authors declare that they have no competing interests.

\section{Author details}

${ }^{1}$ Biotherapy Center and Cancer Center, The First Affiliated Hospital of Zhengzhou University, 1 Jianshe East Road, Zhengzhou 450052, Henan, China. ${ }^{2}$ State Key Laboratory of Esophageal Cancer Prevention and Treatment, Zhengzhou 450052, Henan, China. ${ }^{3}$ Clinical Laboratory, Henan Medical College Hospital Workers, Zhengzhou 450000, Henan, China.

Received: 23 September 2020 Accepted: 28 October 2020

Published online: 10 November 2020

References

1. Siegel RL, Miller KD, Jemal A. Cancer statistics, 2018. CA Cancer J Clin. 2018;68(1):7-30.

2. Hsu T. Educational initiatives in geriatric oncology - Who, why, and how? J Geriat Oncol. 2016;7(5):390-6.

3. Munoz-Espin D, Serrano M. Cellular senescence: from physiology to pathology. Nat Rev Mol Cell Biol. 2014;15(7):482-96.

4. Gorgoulis V, Adams PD, Alimonti A, Bennett DC, Bischof O, Bishop C, Campisi J, Collado M, Evangelou K, Ferbeyre G, et al. Cellular senescence: defining a path forward. Cell. 2019;179(4):813-27.

5. Lopez-Otin C, Blasco MA, Partridge L, Serrano M, Kroemer G. The hallmarks of aging. Cell. 2013;153(6):1194-217.

6. Nacarelli T, Lau L, Fukumoto T, Zundell J, Fatkhutdinov N, Wu S, Aird KM, Iwasaki O, Kossenkov AV, Schultz D, et al. NAD metabolism governs the proinflammatory senescence-associated secretome. Nat Cell Biol. 2019;21(3):397-407.

7. Collado M, Blasco MA, Serrano M. Cellular senescence in cancer and aging. Cell. 2007;130(2):223-33.

8. Yang L, Li A, Lei Q, Zhang Y. Tumor-intrinsic signaling pathways: key roles in the regulation of the immunosuppressive tumor microenvironment. J Hematol Oncol. 2019;12(1):125.

9. Walford RL. The Immunologic Theory of Aging. Gerontologist. 1964:4:195-7.

10. Pawelec G. Age and immunity: What is "immunosenescence"? Exp Gerontol. 2018;105:4-9.

11. Pawelec G. Immunosenescence comes of age. Symposium on Aging Research in Immunology: The Impact of Genomics. EMBO Rep. 2007;8(3):220-3.

12. Pawelec G. Hallmarks of human "immunosenescence": adaptation or dysregulation? Immun Ageing. 2012;9(1):15.

13. Caruso C, Accardi G, Virruso C, Candore G. Sex, gender and immunosenescence: a key to understand the different lifespan between men and women? Immun Ageing. 2013;10(1):20.

14. Turner JE. Is immunosenescence influenced by our lifetime "dose" of exercise? Biogerontology. 2016;17(3):581-602.

15. Accardi G, Caruso C. Immune-inflammatory responses in the elderly: an update. Immun Ageing. 2018;15:11.

16. Aiello A, Accardi G, Candore G, Caruso C, Colomba C, Di Bona D, Duro G, Gambino CM, Ligotti ME, Pandey JP. Role of Immunogenetics in the Outcome of HCMV Infection: Implications for Ageing. Int J Mol Sci. 2019;20(3):685.

17. Ponnappan S, Ponnappan U. Aging and immune function: molecular mechanisms to interventions. Antioxid Redox Signal. 2011;14(8):1551-85

18. Fane M, Weeraratna AT. How the ageing microenvironment influences tumour progression. Nat Rev Cancer. 2020;20(2):89-106.

19. Su D-M, Aw D, Palmer DB. Immunosenescence: a product of the environment? Curr Opin Immunol. 2013;25(4):498-503.

20. Nikolich-Žugich J. Aging of the T cell compartment in mice and humans: from no naive expectations to foggy memories. J Immunol. 2014;193(6):2622-9. 
21. Nikolich-Zugich J. The twilight of immunity: emerging concepts in aging of the immune system. Nat Immunol. 2018;19(1):10-9.

22. Goronzy JJ, Weyand CM. Understanding immunosenescence to improve responses to vaccines. Nat Immunol. 2013;14(5):428-36.

23. Pinti M, Appay V, Campisi J, Frasca D, Fülöp T, Sauce D, Larbi A, Weinberger B, Cossarizza A. Aging of the immune system: Focus on inflammation and vaccination. Eur J Immunol. 2016;46(10):2286-301.

24. Palmer S, Albergante L, Blackburn CC, Newman TJ. Thymic involution and rising disease incidence with age. Proc Natl Acad Sci U S A. 2018;115(8):1883-8

25. Thomas R, Wang W, Su D-M. Contributions of Age-Related Thymic Involution to Immunosenescence and Inflammaging. Immun Ageing. 2020;17:2.

26. Cancro MP, Hao Y, Scholz JL, Riley RL, Frasca D, Dunn-Walters DK, Blomberg BB. B cells and aging: molecules and mechanisms. Trends Immunol. 2009:30(7):313-8.

27. Akbar AN, Henson SM. Are senescence and exhaustion intertwined or unrelated processes that compromise immunity? Nat Rev Immunol. 2011;11(4):289-95.

28. Hazeldine J, Lord JM. Innate immunosenescence: underlying mechanisms and clinical relevance. Biogerontology. 2015;16(2):187-201.

29. Masters AR, Haynes L, Su DM, Palmer DB. Immune senescence: significance of the stromal microenvironment. Clin Exp Immunol. 2017;187(1):6-15.

30. Nguyen V, Mendelsohn A, Larrick JW. Interleukin-7 and Immunosenescence. J Immunol Res. 2017;2017:4807853

31. Crespo J, Sun H, Welling TH, Tian Z, Zou W. T cell anergy, exhaustion, senescence, and stemness in the tumor microenvironment. Curr Opin Immunol. 2013;25(2):214-21.

32. Yang $\mathrm{OO}$, Lin $\mathrm{H}$, Dagarag $\mathrm{M}, \mathrm{Ng} \mathrm{HL}$, Effros RB, Uittenbogaart $\mathrm{CH}$. Decreased perforin and granzyme B expression in senescent HIV1-specific cytotoxic T lymphocytes. Virology. 2005;332(1):16-9.

33. Dimri GP, Lee X, Basile G, Acosta M, Scott G, Roskelley C, Medrano EE, Linskens M, Rubelj I, Pereira-Smith O. A biomarker that identifies senescent human cells in culture and in aging skin in vivo. Proc Natl Acad Sci USA. 1995;92(20):9363-7.

34. Debacq-Chainiaux F, Erusalimsky JD, Campisi J, Toussaint O. Protocols to detect senescence-associated beta-galactosidase (SA-betagal) activity, a biomarker of senescent cells in culture and in vivo. Nat Protoc. 2009:4(12):1798-806.

35. Patsoukis N, Bardhan K, Chatterjee P, Sari D, Liu B, Bell LN, Karoly ED, Freeman GJ, Petkova V, Seth P, et al. PD-1 alters T-cell metabolic reprogramming by inhibiting glycolysis and promoting lipolysis and fatty acid oxidation. Nat Commun. 2015;6:6692.

36. Henson SM, Lanna A, Riddell NE, Franzese O, Macaulay R, Griffiths SJ, Puleston DJ, Watson AS, Simon AK, Tooze SA, et al. p38 signaling inhibits mTORC1-independent autophagy in senescent human CD8+ T cells. J Clin Invest. 2014;124(9):4004-16.

37. Sun Y, Coppé J-P, Lam EWF. Cellular senescence: the sought or the unwanted? Trend Mol Med. 2018;24(10):871-85.

38. Larbi A, Fulop T. From, "truly naïve" to "exhausted senescent"T cells: when markers predict functionality. Cytometry A. 2014;85(1):25-35.

39. Zhao Y, Shao Q, Peng G. Exhaustion and senescence: two crucial dysfunctional states of T cells in the tumor microenvironment. Cell Mol Immunol. 2020;17(1):27-35.

40. Zhang Z, Liu S, Zhang B, Qiao L, Zhang Y, Zhang Y.T Cell dysfunction and exhaustion in cancer. Front Cell Dev Biol. 2020;8:17.

41. Huff WX, Kwon JH, Henriquez M, Fetcko K, Dey M. The evolving role of CD8CD28 Immunosenescent T cells in cancer immunology. Int J Mol Sci. 2019:20(11):2810.

42. Mondal AM, Horikawa I, Pine SR, Fujita K, Morgan KM, Vera E, Mazur SJ, Appella E, Vojtesek B, Blasco MA, et al. p53 isoforms regulate aging- and tumor-associated replicative senescence in T lymphocytes. J Clin Invest. 2013;123(12):5247-57.

43. Liu Y, Sanoff HK, Cho H, Burd CE, Torrice C, Ibrahim JG, Thomas NE, Sharpless NE. Expression of p16(INK4a) in peripheral blood T-cells is a biomarker of human aging. Aging Cell. 2009;8(4):439-48.

44. Bernadotte A, Mikhelson VM, Spivak IM. Markers of cellular senescence. Telomere shortening as a marker of cellular senescence. Aging. 2016:8(1):3-11.
45. Manser AR, Uhrberg M. Age-related changes in natural killer cell repertoires: impact on NK cell function and immune surveillance. Cancer Immunol Immunother. 2016;65(4):417-26.

46. Sanchez-Correa B, Campos C, Pera A, Bergua JM, Arcos MJ, Banas H, Casado JG, Morgado S, Duran E, Solana R, et al. Natural killer cell immunosenescence in acute myeloid leukaemia patients: new targets for immunotherapeutic strategies? Cancer Immunol Immunother. 2016;65(4):453-63.

47. Tahir S, Fukushima Y, Sakamoto K, Sato K, Fujita H, Inoue J, Uede T, Hamazaki Y, Hattori M, Minato N. A CD153+CD4+ T follicular cell population with cell-senescence features plays a crucial role in lupus pathogenesis via osteopontin production. J Immunol. 2015;194(12):5725-35.

48. Wang Y-H, Yu X-H, Luo S-S, Han H. Comprehensive circular RNA profiling reveals that circular RNA100783 is involved in chronic CD28-associated CD8(+)T cell ageing. Immun Ageing. 2015;12:17.

49. DeSantis CE, Miller KD, Dale W, Mohile SG, Cohen HJ, Leach CR, Goding Sauer A, Jemal A, Siegel RL. Cancer statistics for adults aged 85 years and older, 2019. CA: a cancer journal for clinicians. 2019;69(6):452-67.

50. Pelissier Vatter FA, Schapiro D, Chang H, Borowsky AD, Lee JK, Parvin B, Stampfer MR, LaBarge MA, Bodenmiller B, Lorens JB. High-dimensional phenotyping identifies age-emergent cells in human mammary epithelia. Cell Rep. 2018;23(4):1205-19.

51. Ye J, Huang X, Hsueh EC, Zhang Q, Ma C, Zhang Y, Varvares MA, Hoft DF, Peng G. Human regulatory T cells induce T-lymphocyte senescence. Blood. 2012;120(10):2021-31.

52. Ye J, Ma C, Hsueh EC, Eickhoff CS, Zhang Y, Varvares MA, Hoft DF, Peng $G$. Tumor-derived $\gamma \delta$ regulatory $T$ cells suppress innate and adaptive immunity through the induction of immunosenescence. J Immunol. 2013;190(5):2403-14.

53. Liu X, Mo W, Ye J, Li L, Zhang Y, Hsueh EC, Hoft DF, Peng G. Regulatory $T$ cells trigger effector $T$ cell DNA damage and senescence caused by metabolic competition. Nat Commun. 2018;9(1):249.

54. Wang D, Yang L, Yue D, Cao L, Li L, Wang D, Ping Y, Shen Z, Zheng Y, Wang $L$, et al. Macrophage-derived CCL22 promotes an immunosuppressive tumor microenvironment via IL-8 in malignant pleural effusion. Cancer Lett. 2019:452:244-53.

55. Yang L, Zhang Y. Tumor-associated macrophages: from basic research to clinical application. J Hematol Oncol. 2017;10(1):58.

56. Sitkovsky MV, Kjaergaard J, Lukashev D, Ohta A. Hypoxia-adenosinergic immunosuppression: tumor protection by T regulatory cells and cancerous tissue hypoxia. Clin Cancer Res. 2008;14(19):5947-52.

57. Vang T, Torgersen KM, Sundvold V, Saxena M, Levy FO, Skålhegg BS, Hansson V, Mustelin T, Taskén K. Activation of the $\mathrm{COOH}$-terminal Src kinase (Csk) by CAMP-dependent protein kinase inhibits signaling through the T cell receptor. J Exp Med. 2001;193(4):497-507.

58. Salminen A, Kauppinen A, Kaarniranta K. Myeloid-derived suppressor cells (MDSC): an important partner in cellular/tissue senescence. Biogerontology. 2018;19(5):325-39.

59. Wang W, Chen JX, Liao R, Deng Q, Zhou JJ, Huang S, Sun P. Sequential activation of the MEK-extracellular signal-regulated kinase and MKK3/6-p38 mitogen-activated protein kinase pathways mediates oncogenic ras-induced premature senescence. Mol Cell Biol. 2002:22(10):3389-403.

60. Freund A, Patil CK, Campisi J. p38MAPK is a novel DNA damage response-independent regulator of the senescence-associated secretory phenotype. EMBO J. 2011;30(8):1536-48.

61. Van Nguyen T, Puebla-Osorio N, Pang H, Dujka ME, Zhu C. DNA damage-induced cellular senescence is sufficient to suppress tumorigenesis: a mouse model. J Exp Med. 2007;204(6):1453-61.

62. Rodier F, Coppé J-P, Patil CK, Hoeijmakers WAM, Muñoz DP, Raza SR, Freund A, Campeau E, Davalos AR, Campisi J. Persistent DNA damage signalling triggers senescence-associated inflammatory cytokine secretion. Nat Cell Biol. 2009;1 1(8):973-9.

63. Ye J, Ma C, Hsueh EC, Dou J, Mo W, Liu S, Han B, Huang Y, Zhang $Y$, Varvares MA, et al. TLR8 signaling enhances tumor immunity by preventing tumor-induced T-cell senescence. EMBO Mol Med. 2014;6(10):1294-311.

64. Lanna A, Gomes DCO, Muller-Durovic B, McDonnell T, Escors D, Gilroy DW, Lee JH, Karin M, Akbar AN. A sestrin-dependent Erk-Jnk-p38 MAPK activation complex inhibits immunity during aging. Nat Immunol. 2017:18(3):354-63. 
65. Lanna A, Henson SM, Escors D, Akbar AN. The kinase p38 activated by the metabolic regulator AMPK and scaffold TAB1 drives the senescence of human T cells. Nat Immunol. 2014;15(10):965-72.

66. Goronzy JJ, Weyand CM. Mechanisms underlying T cell ageing. Nat Rev Immunol. 2019;19(9):573-83.

67. Onyema OO, Decoster L, Njemini R, Forti LN, Bautmans I, De Waele $M$, Mets T. Chemotherapy-induced changes and immunosenescence of CD8 + T-cells in patients with breast cancer. Anticancer Res. 2015;35(3):1481-9.

68. Sceneay J, Goreczny GJ, Wilson K, Morrow S, DeCristo MJ, Ubellacker JM, Qin Y, Laszewski T, Stover DG, Barrera V, et al. Interferon signaling is diminished with age and is associated with immune checkpoint blockade efficacy in triple-negative breast cancer. Cancer Discov. 2019;9(9):1208-27.

69. Ecker BL, Kaur A, Douglass SM, Webster MR, Almeida FV, Marino GE, Sinnamon AJ, Neuwirth MG, Alicea GM, Ndoye A, et al. Age-related changes in HAPLN1 increase lymphatic permeability and affect routes of melanoma metastasis. Cancer Discov. 2019;9(1):82-95.

70. Kaur A, Webster MR, Marchbank K, Behera R, Ndoye A, Kugel CH, Dang VM, Appleton J, O'Connell MP, Cheng P, et al. SFRP2 in the aged microenvironment drives melanoma metastasis and therapy resistance. Nature. 2016;532(7598):250-4.

71. Oh J, Magnuson A, Benoist C, Pittet MJ, Weissleder R. Age-related tumor growth in mice is related to integrin a 4 in CD8+ T cells. JCl insight. 2018;3(21):e122961

72. Calabrese CT, Adam YG, Volk H. Geriatric colon cancer. Am J Surg. 1973:125(2):181-4.

73. Ershler WB, Socinski MA, Greene CJ. Bronchogenic cancer, metastases, and aging. J Am Geriatr Soc. 1983;31(11):673-6.

74. Ershler WB, Stewart JA, Hacker MP, Moore AL, Tindle BH. B16 murine melanoma and aging: slower growth and longer survival in old mice. J Natl Cancer Inst. 1984;72(1):161-4.

75. Pili R, Guo Y, Chang J, Nakanishi H, Martin GR, Passaniti A. Altered angiogenesis underlying age-dependent changes in tumor growth. J Natl Cancer Inst. 1994:86(17):1303-14.

76. Fisher CJ, Egan MK, Smith P, Wicks K, Millis RR, Fentiman IS. Histopathology of breast cancer in relation to age. Br J Cancer. 1997;75(4):593-6.

77. Gomes AP, Ilter D, Low V, Endress JE, Fernández-García J, Rosenzweig A, Schild T, Broekaert D, Ahmed A, Planque M, et al. Age-induced accumulation of methylmalonic acid promotes tumour progression. Nature. 2020;585(7824):283-7.

78. Ruscetti M, Morris JP, Mezzadra R, Russell J, Leibold J, Romesser PB, Simon J, Kulick A, Ho Y-J, Fennell M, et al. Senescence-induced vascular remodeling creates therapeutic vulnerabilities in pancreas cancer. Cell. 2020;181(2):424-441.e21.

79. Naumova E, Pawelec G, Mihaylova A. Natural killer cells, ageing and cancer. Cancer Immunol Immunother. 2016;65(4):367-70.

80. Habif G, Crinier A, André P, Vivier E, Narni-Mancinelli E. Targeting natural killer cells in solid tumors. Cell Mol Immunol. 2019;16(5):415-22.

81. Shehata HM, Hoebe K, Chougnet CA. The aged nonhematopoietic environment impairs natural killer cell maturation and function. Aging Cell. 2015;14(2):191-9.

82. Fauriat C, Just-Landi S, Mallet F, Arnoulet C, Sainty D, Olive D, Costello RT. Deficient expression of NCR in NK cells from acute myeloid leukemia: Evolution during leukemia treatment and impact of leukemia cells in NCRdull phenotype induction. Blood. 2007;109(1):323-30.

83. Lakshmikanth T, Burke S, Ali TH, Kimpfler S, Ursini F, Ruggeri L, Capanni M, Umansky V, Paschen A, Sucker A, et al. NCRs and DNAM-1 mediate NK cell recognition and lysis of human and mouse melanoma cell lines in vitro and in vivo. J Clin Invest. 2009;119(5):1251-63.

84. Carlsten $M$, Björkström NK, Norell H, Bryceson $Y$, van Hall T, Baumann BC, Hanson M, Schedvins K, Kiessling R, Ljunggren $\mathrm{H}-\mathrm{G}$, et al. DNAX accessory molecule-1 mediated recognition of freshly isolated ovarian carcinoma by resting natural killer cells. Cancer Res. 2007;67(3):1317-25.

85. Campos C, López N, Pera A, Gordillo JJ, Hassouneh F, Tarazona R, Solana R. Expression of NKp30, NKp46 and DNAM-1 activating receptors on resting and IL-2 activated NK cells from healthy donors according to CMV-serostatus and age. Biogerontology. 2015;16(5):671-83.

86. Campos C, Pera A, Sanchez-Correa B, Alonso C, Lopez-Fernandez I, Morgado S, Tarazona R, Solana R. Effect of age and CMV on NK cell subpopulations. Exp Gerontol. 2014;54:130-7.
87. Sanchez-Correa B, Campos C, Pera A, Bergua JM, Arcos MJ, Bañas H, Casado JG, Morgado S, Duran E, Solana R, et al. Natural killer cell immunosenescence in acute myeloid leukaemia patients: new targets for immunotherapeutic strategies? Cancer Immunol Immunother. 2016;65(4):453-63.

88. Tarazona R, Sanchez-Correa B, Casas-Avilés I, Campos C, Pera A, Morgado S, López-Sejas N, Hassouneh F, Bergua JM, Arcos MJ, et al. Immunosenescence: limitations of natural killer cell-based cancer immunotherapy. Cancer Immunol Immunother. 2017;66(2):233-45.

89. Curti A, Ruggeri L, D'Addio A, Bontadini A, Dan E, Motta MR, Trabanelli S, Giudice V, Urbani E, Martinelli G, et al. Successful transfer of alloreactive haploidentical KIR ligand-mismatched natural killer cells after infusion in elderly high risk acute myeloid leukemia patients. Blood. 2011;118(12):3273-9.

90. Goronzy JJ, Fang F, Cavanagh MM, Qi Q, Weyand CM. Naive $T$ cell maintenance and function in human aging. J Immunol. 2015;194(9):4073-80.

91. Qi Q, Zhang DW, Weyand CM, Goronzy JJ. Mechanisms shaping the naïve T cell repertoire in the elderly - thymic involution or peripheral homeostatic proliferation? Exp Gerontol. 2014;54:71-4.

92. Drabkin MJ, Meyer Jl, Kanth N, Lobel S, Fogel J, Grossman J, Krumenacker $\mathrm{JH}$. Age-stratified patterns of thymic involution on multidetector CT. J Thorac Imaging. 2018;33(6):409-16.

93. Hale JS, Boursalian TE, Turk GL, Fink PJ. Thymic output in aged mice. Proc Natl Acad Sci USA. 2006;103(22):8447-52.

94. Rezzani R, Nardo L, Favero G, Peroni M, Rodella LF. Thymus and aging: morphological, radiological, and functional overview. Age (Dordr). 2014;36(1):313-51.

95. Palmer DB. The effect of age on thymic function. Frontiers in immunology. 2013;4:316.

96. Chinn IK, Blackburn CC, Manley NR, Sempowski GD. Changes in primary lymphoid organs with aging. Semin Immunol. 2012;24(5):309-20.

97. Fukushima Y, Minato $N$, Hattori M. The impact of senescence-associated T cells on immunosenescence and age-related disorders. Inflamm Regen. 2018:38:24.

98. Pawelec G. Immunosenescence and cancer. Biogerontology. 2017;18(4):717-21.

99. Goronzy JJ, Weyand CM. Successful and maladaptive T cell aging. Immunity. 2017;46(3):364-78.

100. Pulko V, Davies JS, Martinez C, Lanteri MC, Busch MP, Diamond MS, Knox K, Bush EC, Sims PA, Sinari S, et al. Human memory T cells with a naive phenotype accumulate with aging and respond to persistent viruses. Nat Immunol. 2016;17(8):966-75.

101. Chiu B-C, Martin BE, Stolberg VR, Chensue SW. Cutting edge: Central memory CD8 T cells in aged mice are virtual memory cells. J Immunol. 2013;191(12):5793-6.

102. Quinn KM, Fox A, Harland KL, Russ BE, Li J, Nguyen THO, Loh L, Olshanksy M, Naeem H, Tsyganov K, et al. Age-related decline in primary CD8(+)T cell responses is associated with the development of senescence in virtual memory CD8(+) T cells. Cell Rep. 2018;23(12):3512-24.

103. Jansen CS, Prokhnevska N, Master VA, Sanda MG, Carlisle JW, Bilen MA, Cardenas M, Wilkinson S, Lake R, Sowalsky AG, et al. An intra-tumoral niche maintains and differentiates stem-like CD8 T cells. Nature. 2019;576(7787):465-70.

104. Held W, Siddiqui I, Schaeuble K, Speiser DE. Intratumoral CD8 T cells with stem cell-like properties: implications for cancer immunotherapy. Sci Transl Med. 2019;11(515):eaay6863.

105. Van Epps P, Banks R, Aung H, Betts MR, Canaday DH. Age-related differences in polyfunctional T cell responses. Immun Ageing. 2014;11:14.

106. Di Benedetto S, Derhovanessian E, Steinhagen-Thiessen E, Goldeck D, Müller L, Pawelec G. Impact of age, sex and CMV-infection on peripheral T cell phenotypes: results from the Berlin BASE-II Study. Biogerontology. 2015;16(5):631-43.

107. Ahmed R, Roger L, Costa Del Amo P, Miners KL, Jones RE, Boelen L, Fali T, Elemans M, Zhang Y, Appay V, et al. Human stem cell-like memory $T$ cells are maintained in a state of dynamic flux. Cell reports. 2016:17(11):2811-8.

108. Li M, Yao D, Zeng X, Kasakovski D, Zhang Y, Chen S, Zha X, Li Y, Xu L. Age related human $T$ cell subset evolution and senescence. Immun Ageing. 2019;16:24. 
109. Kared H, Tan SW, Lau MC, Chevrier M, Tan C, How W, Wong G, Strickland $\mathrm{M}$, Malleret B, Amoah A, et al. Immunological history governs human stem cell memory CD4 heterogeneity via the Wnt signaling pathway. Nat Commun. 2020;11(1):821.

110. Im A, Pavletic SZ. Immunotherapy in hematologic malignancies: past, present, and future. J Hematol Oncol. 2017;10(1):94.

111. Yu S, Li A, Liu Q, Li T, Yuan X, Han X, Wu K. Chimeric antigen receptor T cells: a novel therapy for solid tumors. J Hematol Oncol. 2017;10(1):78.

112. Sun W. Recent advances in cancer immunotherapy. J Hematol Oncol. 2017;10(1):96

113. Lichtenegger FS, Krupka C, Haubner S, Köhnke T, Subklewe M. Recent developments in immunotherapy of acute myeloid leukemia. J Hematol Oncol. 2017;10(1):142.

114. Wei G, Ding L, Wang J, Hu Y, Huang H. Advances of CD19-directed chimeric antigen receptor-modified T cells in refractory/relapsed acute lymphoblastic leukemia. Exp Hematol Oncol. 2017;6:10.

115. Zhang C, Liu J, Zhong JF, Zhang X. Engineering CAR-T cells. Biomark Res. 2017;5:22.

116. Qin L, Zhao R, Li P. Incorporation of functional elements enhances the antitumor capacity of CART cells. Exp Hematol Oncol. 2017;6:28.

117. Sidaway P. Immunotherapy: CART cell therapy efficacious against B-ALL across age groups. Nat Rev Clin Oncol. 2018;15(4):199.

118. Maude SL, Laetsch TW, Buechner J, Rives S, Boyer M, Bittencourt H, Bader P, Verneris MR, Stefanski HE, Myers GD, et al. Tisagenlecleucel in children and young adults with B-cell lymphoblastic leukemia. N Engl J Med. 2018;378(5):439-48.

119. Park JH, Rivière I, Gonen M, Wang X, Sénéchal B, Curran KJ, Sauter C, Wang Y, Santomasso B, Mead E, et al. Long-term follow-up of CD19 CAR therapy in acute lymphoblastic Leukemia. N Engl J Med. 2018;378(5):449-59.

120. Stirrups R. CAR T-cells for relapsed B-cell ALL in children and young adults. Lancet Oncol. 2018;19(3):e144.

121. Kasakovski D, Xu L, Li Y.T cell senescence and CAR-T cell exhaustion in hematological malignancies. J Hematol Oncol. 2018;11(1):91.

122. Ye B, Stary CM, Li X, Gao Q, Kang C, Xiong X. Engineering chimeric antigen receptor-T cells for cancer treatment. Mol Cancer. 2018;17(1):32

123. Yao D, Xu L, Tan J, Zhang Y, Lu S, Li M, Lu S, Yang L, Chen S, Chen J, et al. Re-balance of memory $T$ cell subsets in peripheral blood from patients with CML after TKI treatment. Oncotarget. 2017;8(47):81852-9.

124. Zhu X, Niedermann G. Rapid and efficient transfer of the T cell aging marker CD57 from glioblastoma stem cells to CART cells. Oncoscience. 2015;2(5):476-82.

125. Zhu X, Prasad S, Gaedicke S, Hettich M, Firat E, Niedermann G. Patientderived glioblastoma stem cells are killed by CD133-specific CART cells but induce the T cell aging marker CD57. Oncotarget. 2015;6(1):171-84.

126. Yang $Y$, Kohler $M E$, Chien $C D$, Sauter $C T$, Jacoby E, Yan C, Hu Y, Wanhainen K, Qin H, Fry TJ. TCR engagement negatively affects CD8 but not CD4 CART cell expansion and leukemic clearance. Sci Transl Med. 2017;9(417):eaag1209.

127. Amor C, Feucht J, Leibold J, Ho Y-J, Zhu C, Alonso-Curbelo D, MansillaSoto J, Boyer JA, Li X, Giavridis T, et al. Senolytic CART cells reverse senescence-associated pathologies. Nature. 2020;583(7814):127-32.

128. Fornara O, Odeberg J, Wolmer Solberg N, Tammik C, Skarman P, Peredo I, Stragliotto G, Rahbar A, Soderberg-Naucler C. Poor survival in glioblastoma patients is associated with early signs of immunosenescence in the CD4 T-cell compartment after surgery. Oncoimmunology. 2015:4(9):e1036211.

129. Shimatani K, Nakashima Y, Hattori M, Hamazaki Y, Minato N. PD-1+ memory phenotype CD4+ T cells expressing C/EBPalpha underlie T cell immunodepression in senescence and leukemia. Proc Natl Acad Sci USA. 2009;106(37):15807-12.

130. Fang F, Yu M, Cavanagh MM, Hutter Saunders J, Qi Q, Ye Z, Le Saux S, Sultan W, Turgano E, Dekker CL, et al. Expression of CD39 on activated $T$ cells impairs their survival in older individuals. Cell Rep. 2016;14(5):1218-31

131. Elyahu Y, Hekselman I, Eizenberg-Magar I, Berner O, Strominger I, Schiller M, Mittal K, Nemirovsky A, Eremenko E, Vital A, et al. Aging promotes reorganization of the CD4 T cell landscape toward extreme regulatory and effector phenotypes. Sci Adv. 2019;5(8):eaaw8330.
132. Kozlowska E, Biernacka M, Ciechomska M, Drela N. Age-related changes in the occurrence and characteristics of thymic CD4(+) CD25(+) T cells in mice. Immunology. 2007;122(3):445-53.

133. Thomas DC, Mellanby RJ, Phillips JM, Cooke A. An early age-related increase in the frequency of CD4+ Foxp3+ cells in BDC2.5NOD mice. Immunology. 2007;121(4):565-76.

134. Zhao L, Sun L, Wang H, Ma H, Liu G, Zhao Y. Changes of CD4+CD25+Foxp3+ regulatory T cells in aged Balb/c mice. J Leukoc Biol. 2007;81(6):1386-94.

135. Pan X-D, Mao Y-Q, Zhu L-J, Li J, Xie Y, Wang L, Zhang G-B. Changes of regulatory $T$ cells and FoxP3 gene expression in the aging process and its relationship with lung tumors in humans and mice. Chin Med J (Engl). 2012;125(11):2004-11.

136. Gong Z, Jia Q, Chen J, Diao X, Gao J, Wang X, Zhu B. Impaired cytolytic activity and loss of clonal neoantigens in elderly patients with lung adenocarcinoma. J Thorac Oncol. 2019;14(5):857-66.

137. Wang S-S, Liu W, Ly D, Xu H, Qu L, Zhang L. Tumor-infiltrating B cells: their role and application in anti-tumor immunity in lung cancer. Cell Mol Immunol. 2019;16(1):6-18.

138. Hagen $\mathrm{M}$, Derudder E. Inflammation and the alteration of B-Cell physiology in aging. Gerontology. 2020;66(2):105-13.

139. Labi V, Derudder E. Cell signaling and the aging of B cells. Exp Gerontol. 2020;138:110985.

140. Bulati M, Caruso C, Colonna-Romano G. From lymphopoiesis to plasma cells differentiation, the age-related modifications of $B$ cell compartment are influenced by "inflamm-ageing." Ageing Res Rev. 2017;36:125-36.

141. Kogut I, Scholz JL, Cancro MP, Cambier JC. B cell maintenance and function in aging. Semin Immunol. 2012;24(5):342-9.

142. Cepeda S, Cantu C, Orozco S, Xiao Y, Brown Z, Semwal MK, Venables T, Anderson MS, Griffith AV. Age-associated decline in thymic $B$ cell expression of aire and aire-dependent self-antigens. Cell Rep. 2018;22(5):1276-87.

143. Johnson KM, Owen K, Witte PL. Aging and developmental transitions in the B cell lineage. Int Immunol. 2002;14(11):1313-23.

144. Kline GH, Hayden TA, Klinman NR. B cell maintenance in aged mice reflects both increased B cell longevity and decreased B cell generation. J Immunol. 1999:162(6):3342-9.

145. Agrawal A, Gupta S. Impact of aging on dendritic cell functions in humans. Ageing Res Rev. 2011;10(3):336-45.

146. Gardner JK, Mamotte CDS, Jackaman C, Nelson DJ. Modulation of dendritic cell and T cell cross-talk during aging: the potential role of checkpoint inhibitory molecules. Ageing Res Rev. 2017;38:40-51.

147. Jackaman C, Tomay F, Duong L, Abdol Razak NB, Pixley FJ, Metharom P, Nelson DJ. Aging and cancer: the role of macrophages and neutrophils. Ageing Res Rev. 2017;36:105-16.

148. He Y-M, Li X, Perego M, Nefedova Y, Kossenkov AV, Jensen EA, Kagan V, Liu Y-F, Fu S-Y, Ye Q-J, et al. Transitory presence of myeloid-derived suppressor cells in neonates is critical for control of inflammation. Nat Med. 2018;24(2):224-31.

149. Salminen A, Kauppinen A, Kaarniranta K. AMPK activation inhibits the functions of myeloid-derived suppressor cells (MDSC): impact on cancer and aging. J Mol Med (Berl). 2019:97(8):1049-64.

150. Scher KS, Hurria A. Under-representation of older adults in cancer registration trials: known problem, little progress. J Clin Oncol. 2012;30(17):2036-8.

151. Mohile SG, Dale W, Somerfield MR, Hurria A. Practical assessment and management of vulnerabilities in older patients receiving chemotherapy: ASCO guideline for geriatric oncology summary. J Oncol Pract. 2018;14(7):442-6.

152. Ferrara R, Mezquita L, Auclin E, Chaput N, Besse B. Immunosenescence and immunecheckpoint inhibitors in non-small cell lung cancer patients: does age really matter? Cancer Treat Rev. 2017;60:60-8.

153. Padron A, Hurez V, Gupta HB, Clark CA, Pandeswara SL, Yuan B, Svatek RS, Turk MJ, Drerup JM, Li R, et al. Age effects of distinct immune checkpoint blockade treatments in a mouse melanoma model. Exp Gerontol. 2018;105:146-54.

154. Kugel CH 3rd, Douglass SM, Webster MR, Kaur A, Liu Q, Yin X, Weiss SA, Darvishian F, Al-Rohil RN, Ndoye A, et al. Age Correlates with response to Anti-PD1, reflecting age-related differences in intratumoral effector and regulatory T-cell populations. Clin Cancer Res. 2018;24(21):5347-56. 
155. Elias R, Giobbie-Hurder A, McCleary NJ, Ott P, Hodi FS, Rahma O. Efficacy of PD-1 \& PD-L1 inhibitors in older adults: a meta-analysis. J Immunother Cancer. 2018;6(1):26.

156. Li P, Yang X, Feng Y, Wu L, Ma W, Ding G, Wei Y, Sun L. The impact of immunosenescence on the efficacy of immune checkpoint inhibitors in melanoma patients: a meta-analysis. Onco Targets Ther. 2018;11:7521-7.

157. Marur S, Singh H, Mishra-Kalyani P, Larkins E, Keegan P, Sridhara R, Blumenthal GM, Pazdur R. FDA analyses of survival in older adults with metastatic non-small cell lung cancer in controlled trials of PD-1/PD-L1 blocking antibodies. Semin Oncol. 2018;45(4):220-5.

158. Nishijima TF, Muss HB, Shachar SS, Moschos SJ. Comparison of efficacy of immune checkpoint inhibitors (ICIs) between younger and older patients: a systematic review and meta-analysis. Cancer Treat Rev. 2016:45:30-7.

159. Wang DY, Salem JE, Cohen JV, Chandra S, Menzer C, Ye F, Zhao S, Das S, Beckermann $\mathrm{KE}, \mathrm{Ha} \mathrm{L}$, et al. Fatal toxic effects associated with immune checkpoint inhibitors: a systematic review and meta-analysis. JAMA Oncol. 2018;4(12):1721-8.

160. Ridolfi L, De Rosa F, Petracci E, Tanda ET, Marra E, Pigozzo J, Marconcini R, Guida M, Cappellini GCA, Gallizzi G, et al. Anti-PD1 antibodies in patients aged $>/=75$ years with metastatic melanoma: a retrospective multicentre study. J Geriatr Oncol. 2020;11(3):515-22.

161. Sekido K, Tomihara K, Tachinami H, Heshiki W, Sakurai K, Moniruzzaman R, Imaue S, Fujiwara K, Noguchi M. Alterations in composition of immune cells and impairment of anti-tumor immune response in aged oral cancer-bearing mice. Oral Oncol. 2019;99:104462.

162. Belgioia L, Desideri I, Errico A, Franzese C, Daidone A, Marino L, Fiore M, Borghetti P, Greto D, Fiorentino A, et al. Safety and efficacy of combined radiotherapy, immunotherapy and targeted agents in elderly patients: a literature review. Crit Rev Oncol Hematol. 2019:133:163-70.

163. Niccoli T, Partridge L. Ageing as a risk factor for disease. Curr Biol. 2012;22(17):R741-52.

164. St Sauver JL, Boyd CM, Grossardt BR, Bobo WV, Finney Rutten $L$, Roger VL, Ebbert JO, Therneau TM, Yawn BP, Rocca WA. Risk of developing multimorbidity across all ages in an historical cohort study: differences by sex and ethnicity. BMJ Open. 2015;5(2):e006413.

165. Pignolo RJ, Passos JF, Khosla S, Tchkonia T, Kirkland JL. Reducing senescent cell burden in aging and disease. Trends in molecular medicine. 2020;26(7):630-8.

166. Campisi J, Kapahi P, Lithgow GJ, Melov S, Newman JC, Verdin E. From discoveries in ageing research to therapeutics for healthy ageing. Nature. 2019;571(7764):183-92.

167. McCay CM, Maynard LA, Sperling G, Barnes LL. The Journal of Nutrition. Volume 18 July--December, 1939. Pages 1--13. Retarded growth, life span, ultimate body size and age changes in the albino rat after feeding diets restricted in calories. Nutrit Rev. 1975;33(8):241-43.

168. Mattison JA, Colman RJ, Beasley TM, Allison DB, Kemnitz JW, Roth GS, Ingram DK, Weindruch R, de Cabo R, Anderson RM. Caloric restriction improves health and survival of rhesus monkeys. Nat Commun 2017:8:14063.

169. Pifferi F, Terrien J, Marchal J, Dal-Pan A, Djelti F, Hardy I, Chahory S, Cordonnier N, Desquilbet L, Hurion M, et al. Caloric restriction increases lifespan but affects brain integrity in grey mouse lemur primates. Commun Biol. 2018;1:30

170. Omodei D, Fontana L. Calorie restriction and prevention of age-associated chronic disease. FEBS Lett. 2011;585(11):1537-42.

171. Kim M-J, Miller CM, Shadrach JL, Wagers AJ, Serwold T. Young, proliferative thymic epithelial cells engraft and function in aging thymuses. J Immunol. 2015;194(10):4784-95.

172. Sun L, Guo J, Brown R, Amagai T, Zhao Y, Su D-M. Declining expression of a single epithelial cell-autonomous gene accelerates age-related thymic involution. Aging Cell. 2010;9(3):347-57.

173. Henson SM, Snelgrove R, Hussell T, Wells DJ, Aspinall R. An IL-7 fusion protein that shows increased thymopoietic ability. J Immunol. 2005:175(6):4112-8

174. Duggal NA, Pollock RD, Lazarus NR, Harridge S, Lord JM. Major features of immunosenescence, including reduced thymic output, are ameliorated by high levels of physical activity in adulthood. Aging Cell. 2018;17(2):e12750.
175. Muñoz-Lorente MA, Cano-Martin AC, Blasco MA. Mice with hyper-long telomeres show less metabolic aging and longer lifespans. Nat Commun. 2019;10(1):4723.

176. Partridge L, Fuentealba M, Kennedy BK. The quest to slow ageing through drug discovery. Nat Rev Drug Discov. 2020;19(8):513-32.

177. Barzilai N, Crandall JP, Kritchevsky SB, Espeland MA. Metformin as a Tool to Target Aging. Cell Metab. 2016;23(6):1060-5.

178. Anisimov VN. Metformin: do we finally have an anti-aging drug? Cell Cycle. 2013;12(22):3483-9.

179. Strong R, Miller RA, Antebi A, Astle CM, Bogue M, Denzel MS, Fernandez E, Flurkey K, Hamilton KL, Lamming DW, et al. Longer lifespan in male mice treated with a weakly estrogenic agonist, an antioxidant, an a-glucosidase inhibitor or a Nrf2-inducer. Aging Cell. 2016;15(5):872-84.

180. Martin-Montalvo A, Mercken EM, Mitchell SJ, Palacios HH, Mote PL, Scheibye-Knudsen M, Gomes AP, Ward TM, Minor RK, Blouin M-J, et al. Metformin improves healthspan and lifespan in mice. Nat Commun. 2013;4:2192.

181. Bannister CA, Holden SE, Jenkins-Jones S, Morgan CL, Halcox JP, Schernthaner G, Mukherjee J, Currie CJ. Can people with type 2 diabetes live longer than those without? A comparison of mortality in people initiated with metformin or sulphonylurea monotherapy and matched, non-diabetic controls. Diabetes Obes Metab. 2014;16(11):1165-73.

182. Kapahi P, Chen D, Rogers AN, Katewa SD, Li PW-L, Thomas EL, Kockel $L$. With TOR, less is more: a key role for the conserved nutrient-sensing TOR pathway in aging. Cell Metab. 2010;1 16):453-65.

183. Ha CW, Huh W-K. Rapamycin increases rDNA stability by enhancing association of Sir2 with rDNA in Saccharomyces cerevisiae. Nucleic Acids Res. 2011;39(4):1336-50

184. Harrison DE, Strong R, Sharp ZD, Nelson JF, Astle CM, Flurkey K, Nadon NL, Wilkinson JE, Frenkel K, Carter CS, et al. Rapamycin fed late in life extends lifespan in genetically heterogeneous mice. Nature. 2009:460(7253):392-5.

185. Miller RA, Harrison DE, Astle CM, Baur JA, Boyd AR, de Cabo R, Fernandez E, Flurkey K, Javors MA, Nelson JF, et al. Rapamycin, but not resveratrol or simvastatin, extends life span of genetically heterogeneous mice. J Gerontol Ser A Biol Sci Med Sci. 2011;66(2):191-201.

186. Kapahi P, Kaeberlein M, Hansen M. Dietary restriction and lifespan: Lessons from invertebrate models. Ageing Res Rev. 2017;39:3-14.

187. Popovich IG, Anisimov VN, Zabezhinski MA, Semenchenko AV, Tyndyk ML, Yurova MN, Blagosklonny MV. Lifespan extension and cancer prevention in HER-2/neu transgenic mice treated with low intermittent doses of rapamycin. Cancer Biol Ther. 2014:15(5):586-92.

188. Grabiner BC, Nardi V, Birsoy K, Possemato R, Shen K, Sinha S, Jordan A, Beck AH, Sabatini DM. A diverse array of cancer-associated MTOR mutations are hyperactivating and can predict rapamycin sensitivity. Cancer Discov. 2014:4(5):554-63.

189. Xu J, Pham CG, Albanese SK, Dong Y, Oyama T, Lee C-H, Rodrik-Outmezguine V, Yao Z, Han S, Chen D, et al. Mechanistically distinct cancerassociated mTOR activation clusters predict sensitivity to rapamycin. J Clin Invest. 2016;126(9):3526-40.

190. Neff F, Flores-Dominguez D, Ryan DP, Horsch M, Schröder S, Adler T, Afonso LC, Aguilar-Pimentel JA, Becker L, Garrett L, et al. Rapamycin extends murine lifespan but has limited effects on aging. J Clin Invest. 2013;123(8):3272-91.

191. Wilkinson JE, Burmeister L, Brooks SV, Chan C-C, Friedline S, Harrison DE, Hejtmancik JF, Nadon N, Strong R, Wood LK, et al. Rapamycin slows aging in mice. Aging Cell. 2012;11(4):675-82.

192. Sung JY, Lee KY, Kim J-R, Choi HC. Interaction between mTOR pathway inhibition and autophagy induction attenuates adriamycin-induced vascular smooth muscle cell senescence through decreased expressions of p53/p21/p16. Exp Gerontol. 2018;109:51-8.

193. Wang R, Sunchu B, Perez VI. Rapamycin and the inhibition of the secretory phenotype. Exp Gerontol. 2017;94:89-92.

194. Wang R, Yu Z, Sunchu B, Shoaf J, Dang I, Zhao S, Caples K, Bradley L, Beaver $L M, H o E$, et al. Rapamycin inhibits the secretory phenotype of senescent cells by a Nrf2-independent mechanism. Aging Cell. 2017;16(3):564-74.

195. Rajman L, Chwalek K, Sinclair DA. Therapeutic potential of NAD-boosting molecules: the in vivo evidence. Cell Metab. 2018;27(3):529-47.

196. Verdin E. NAD+ in aging, metabolism, and neurodegeneration. Science (New York, NY). 2015;350(6265):1208-13. 
197. Yoshino J, Baur JA, Imai S-I. NAD intermediates: the biology and therapeutic potential of NMN and NR. Cell Metab. 2018;27(3):513-28.

198. Garten A, Schuster S, Penke M, Gorski T, de Giorgis T, Kiess W. Physiological and pathophysiological roles of NAMPT and NAD metabolism. Nat Rev Endocrinol. 2015;11(9):535-46.

199. Hikosaka K, Yaku K, Okabe K, Nakagawa T. Implications of NAD metabolism in pathophysiology and therapeutics for neurodegenerative diseases. Nutr Neurosci. 2019;1-13.

200. Belenky P, Racette FG, Bogan KL, McClure JM, Smith JS, Brenner C. Nicotinamide riboside promotes Sir2 silencing and extends lifespan via Nrk and Urh1/Pnp1/Meu1 pathways to NAD+. Cell. 2007;129(3):473-84.

201. Mouchiroud L, Houtkooper RH, Moullan N, Katsyuba E, Ryu D, Cantó C, Mottis A, Jo Y-S, Viswanathan M, Schoonjans K, et al. The NAD(+)/sirtuin pathway modulates longevity through activation of mitochondrial UPR and FOXO signaling. Cell. 2013;154(2):430-41.

202. Zhang H, Ryu D, Wu Y, Gariani K, Wang X, Luan P, D'Amico D, Ropelle ER, Lutolf MP, Aebersold R, et al. NAD+ repletion improves mitochondrial and stem cell function and enhances life span in mice. Science (New York, NY). 2016;352(6292):1436-43.

203. de Picciotto NE, Gano LB, Johnson LC, Martens CR, Sindler AL, Mills KF, Imai S-I, Seals DR. Nicotinamide mononucleotide supplementation reverses vascular dysfunction and oxidative stress with aging in mice. Aging Cell. 2016;15(3):522-30

204. Gomes AP, Price NL, Ling AJY, Moslehi JJ, Montgomery MK, Rajman L, White JP, Teodoro JS, Wrann CD, Hubbard BP, et al. Declining NAD(+) induces a pseudohypoxic state disrupting nuclear-mitochondrial communication during aging. Cell. 2013:155(7):1624-38.

205. Mills KF, Yoshida S, Stein LR, Grozio A, Kubota S, Sasaki Y, Redpath P, Migaud ME, Apte RS, Uchida K, et al. Long-term administration of nicotinamide mononucleotide mitigates age-associated physiological decline in mice. Cell Metab. 2016;24(6):795-806.

206. Stein LR, Imai S-i. Specific ablation of Nampt in adult neural stem cells recapitulates their functional defects during aging. EMBO J. 2014;33(12):1321-40.

207. Ramsey KM, Mills KF, Satoh A, Imai S-I. Age-associated loss of Sirt1mediated enhancement of glucose-stimulated insulin secretion in beta cell-specific Sirt1-overexpressing (BESTO) mice. Aging Cell. 2008;7(1):78-88.

208. Grozio A, Mills KF, Yoshino J, Bruzzone S, Sociali G, Tokizane K, Lei HC, Cunningham R, Sasaki Y, Migaud ME, et al. Slc12a8 is a nicotinamide mononucleotide transporter. Nat Metab. 2019;1(1):47-57.

209. Davis MM. A prescription for human immunology. Immunity. 2008;29(6):835-8.

210. Dutta S, Sengupta P. Men and mice: relating their ages. Life Sci. 2016:152:244-8.

211. Alpert A, Pickman Y, Leipold M, Rosenberg-Hasson Y, Ji X, Gaujoux R, Rabani H, Starosvetsky E, Kveler K, Schaffert S, et al. A clinically meaningful metric of immune age derived from high-dimensional longitudinal monitoring. Nat Med. 2019;25(3):487-95.

212. Bonkowski MS, Sinclair DA. Slowing ageing by design: the rise of $\mathrm{NAD}(+)$ and sirtuin-activating compounds. Nat Rev Mol Cell Biol. 2016;17(11):679-90.

\section{Publisher's Note}

Springer Nature remains neutral with regard to jurisdictional claims in published maps and institutional affiliations.
Ready to submit your research? Choose BMC and benefit from:

- fast, convenient online submission

- thorough peer review by experienced researchers in your field

- rapid publication on acceptance

- support for research data, including large and complex data types

- gold Open Access which fosters wider collaboration and increased citations

- maximum visibility for your research: over $100 \mathrm{M}$ website views per year

At BMC, research is always in progress.

Learn more biomedcentral.com/submissions 